\title{
Review Article \\ Psychiatric Morbidity and Other Factors Affecting Treatment Adherence in Pulmonary Tuberculosis Patients
}

\author{
Argiro Pachi, Dionisios Bratis, Georgios Moussas, and Athanasios Tselebis \\ Psychiatric Department, Sotiria General Hospital of Chest Disease, Athens, Greece \\ Correspondence should be addressed to Athanasios Tselebis; atselebis@yahoo.gr
}

Received 30 April 2012; Revised 3 January 2013; Accepted 7 February 2013

Academic Editor: Jeffrey R. Starke

Copyright (C) 2013 Argiro Pachi et al. This is an open access article distributed under the Creative Commons Attribution License, which permits unrestricted use, distribution, and reproduction in any medium, provided the original work is properly cited.

\begin{abstract}
As the overall prevalence of TB remains high among certain population groups, there is growing awareness of psychiatric comorbidity, especially depression and its role in the outcome of the disease. The paper attempts a holistic approach to the effects of psychiatric comorbidity to the natural history of tuberculosis. In order to investigate factors associated with medication nonadherence among patients suffering from tuberculosis, with emphasis on psychopathology as a major barrier to treatment adherence, we performed a systematic review of the literature on epidemiological data and past medical reviews from an historical perspective, followed by theoretical considerations upon the relationship between psychiatric disorders and tuberculosis. Studies reporting high prevalence rates of psychiatric comorbidity, especially depression, as well as specific psychological reactions and disease perceptions and reviews indicating psychiatric complications as adverse effects of anti-TB medication were included. In sum, data concerning factors affecting medication nonadherence among TB patients suggested that better management of comorbid conditions, especially depression, could improve the adherence rates, serving as a framework for the effective control of tuberculosis, but further studies are necessary to identify the optimal way to address such issues among these patients.
\end{abstract}

\section{Introduction}

Tuberculosis (TB) is a chronic infectious multisystemic disease caused by mycobacterium tuberculosis [1] and is one of the leading causes of mortality worldwide [2-4]. The World Health Organization (WHO) has estimated that 2 billion people, almost a third of the world's population, have latent TB $[5,6]$. Every year about eight million people develop this disease, and some three million die of it, over $95 \%$ of these from developing countries [7, 8]. In 2005 the highest rates per capital were from Africa ( $28 \%$ of all TB cases), and half of all new cases were from six Asian countries, namely, Bangladesh, China, India, Indonesia, Pakistan, and the Philippines $[9,10]$.

Beginning in 1985, a resurgence [11-14] of TB was observed, primarily in certain groups, including the homeless [15], those who are HIV seropositive [16], individuals with a history of alcohol or drug abuse [17], and immigrants from a country in which TB is endemic [18].

Many recipients of psychiatric services possess one or more of these risk factors $[19,20]$, and, consequently, TB may be overrepresented in this population. Conversely, psychiatric illness may develop subsequent to TB infection, and mood disorders seem to be particularly common in TB patients compared with those with other medical diagnoses [21-24].

The World Health Organization's (WHO) goal of tuberculosis control remains elusive $[25,26]$, and this failure has been blamed on numerous factors such as inadequate emphasis on human dimension of tuberculosis control [27-29] which includes nonadherence with medication and results in multidrug resistance and therapeutic failure [30,31].

The purpose of this study is to investigate factors associated with medication nonadherence among patients suffering from tuberculosis with emphasis on psychopathology as a major barrier to treatment adherence [32, 33].

The literature indicates that psychiatric comorbidity [34] before and after tuberculosis onset, psychological issues such as stigma [35], isolation [36], sense of social support [37], helplessness [38], and other psychological reactions to the 


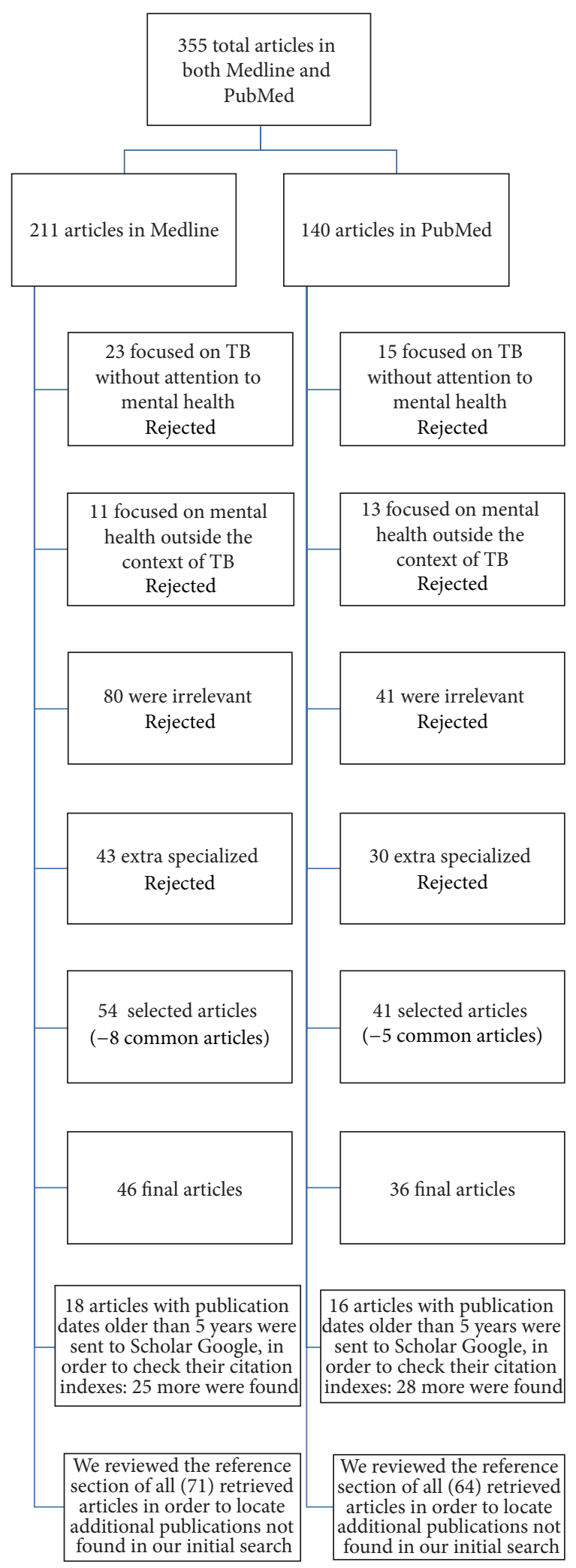

FIGURE 1: Consort diagram of the method.

disclosure of the diagnosis [39] as well as medication sideeffects [40], all adversely affect the treatment adherence.
On the other hand, studies report high prevalence rates of psychiatric comorbidity among patients with drug-resistant tuberculosis [40] and that prevalence of depression significantly correlates with severity and duration of the disease $[41,42]$.

The causal relationships between mental disorders and tuberculosis are complex. Severe mental disorders are associated with high risk of tuberculosis acquisition and transmission [43] and with poorer adherence to anti-TB treatment. Conversely, diagnosis with tuberculosis increases risk of psychiatric comorbidity.

Only by taking these observations together along with the fact that the prevalence of tuberculosis rises in specific groups [179] especially among individuals who are more likely to be psychologically distressed than the general population, such as homeless, immigrants, and HIV patients, does a complete picture emerge, and researchers conclude that in order to increase the cure rates of tuberculosis psychiatric, comorbidity must be firstly identified and treated [82].

\section{Method}

2.1. Search Strategy. Using the terms "tuberculosis and mental illness," "anxiety and depression in tuberculosis," "risk factors for nonadherence to tuberculosis treatment," and "psychiatric and antitubercular drugs," we searched Medline and using the terms "mental illness stigma and tuberculosis," "mental illness primary care and tuberculosis," and "tuberculosis nonadherence and psychosocial factors," we searched PubMed. Articles were restricted to English, and publication dates were from 1950 to 2012. This yielded 355 articles. However, after excluding 38 articles that focused on TB without attention to mental health, 24 articles on mental health outside the context of TB and another 121 irrelevant and 73 extra specialized articles outside our primary focus, 94 articles were found, but 82 were kept for review, after excluding common articles. Then, 34 articles with publication dates older than 5 years were sent to Scholar Google in order to check their citation indexes. With this method, we located 53 additional articles with publication dates during the last 5 years. We reviewed the reference section of all (135) retrieved articles in order to locate additional publications not found in our initial search (Consort diagram-Figure 1).

We reviewed each article, noting date of publication, key results, and conclusions and then assigned the articles to different categories according to our primary focus.

Firstly, we reviewed the past medical literature, from an historical perspective. Then, we theorized upon issues regarding the complex interrelation and interaction between psychiatric disorders and tuberculosis, followed by accumulated data and results from clinical studies indicating prevalence rates of psychiatric comorbidity and specific psychological reactions and disease perceptions in tuberculous patients. Afterwards, we performed a review of the literature on psychiatric disorders in patients receiving antituberculosis drugs, possibly resulting in comorbid states as well as in treatment interruption which compromises treatment efficacy leading to cases of high-grade drug resistance. 
TABLE 1: Categories of psychiatric conditions in TB patients.

Psychiatric conditions arising after TB are diagnosed (as reactions to the medical illness or a direct physiological consequence of the illness)—according to DSM-IV:

(i) adjustment disorder,

(ii) mood disorders (e.g., major depression),

(1) (iii) anxiety disorders (e.g., PTSD, acute stress disorder, and GAD),

(iv) somatoform disorders (e.g., pain disorders and neurasthenia),

(v) delirium and other cognitive disorders,

(vi) personality change due to a general medical condition.

Differential diagnosis in this category is necessary between a psychosocial issue and a diagnosable mental disorder.

(2) Psychiatric complications associated with antituberculosis therapy.

(3) Preexisting psychiatric disorders potentially increasing risk of TB and risk of progression from latent TB infection to active TB (e.g., substance related disorders, psychotic disorders, mood disorders, and psychological factors affecting medical condition).

(4) Coexisting psychiatric disorders exacerbated by TB, without necessarily being etiologically related but complicate the diagnosis and management and can alter its course (e.g., specific phobia).

(5) Comorbidity as a result of commonly shared risk factors for the development of a variety of psychiatric disorders and TB (e.g., substance related disorders and low socioeconomic status).

Finally, we summarized factors affecting treatment adherence, and we concluded that management of psychiatric complications, especially depression which is more prevalent in tuberculosis, is necessary and possible without compromising antituberculosis treatment.

\section{Results}

The literature review yielded in sum 135 articles: 4 on epidemiology, 3 on the past medical literature, 59 on results from clinical studies on psychiatric comorbidity in TB patients, 12 on psychological reactions and disease perceptions, 28 on psychiatric disorders in patients receiving anti-TB drugs, 17 on factors affecting medication nonadherence, and 12 on interactions involving $\mathrm{TB}$ medications and psychiatric medications. The overall citations are many more since we reviewed the reference section of these retrieved articles.

\section{Psychiatry and Tuberculosis}

4.1. A Review of the Literature. The psychological aspects of tuberculosis have always been a topic of interest over the centuries [180-182] and the association of tuberculosis and mental illness became a subject of statistical analysis as early as 1863 [183]. Clouston analyzed the deaths from tuberculosis in an Edinburgh asylum, after comparing figures from La Salpetriere and a New York state asylum and raised the question if conditions of living in asylums favor the development of tuberculosis or there is a special relationship between tuberculosis and insanity. Later, studies [184] in New York state hospitals indicated that prevalence rates of tuberculosis, diagnosed by X-rays findings, increased with the length of time between first admission and the X-ray survey, emphasizing the role of the contagious factor [185].

Concerning psychopathology of tuberculosis, Jacobson firstly observed that some tuberculous patients are euphoric and appear totally unaware of the gravity of their illness [186]. This clinical observation was later rejected by other studies $[187,188]$. When attempting to describe the personality of tuberculous patients some writers implied that the number of neurotics among them was greater than the number encountered among the general population [187-189], but figures are lacking. When figures do come up, Day [190] believed that $30 \%$ of patients he observed in an English sanatorium were "ill of mind," Breuer [191] reported that for $34 \%$ of his patients, tuberculosis was "psychologically determined," and Forster and Shepard [192] found that 31\% of tuberculous patients in Cragmor Sanatorium were suffering from an "abnormal mental state." Bobrowitz [193] mentioned that from $20 \%$ to $50 \%$ of patients of the Otisville Sanatorium in New York leave against advice mainly for psychological reasons and Ashmore and Bell [194] found that among veterans tuberculous patients who left against advice in their first year of treatment, chronic alcoholism, psychopathy, and ignorance, all played a part. Also, tuberculous patients have been psychoanalyzed by Jelliffe and Evans [195] who concluded that they were "childish, selfish, self-centered, irritable, dissatisfied, and ungrateful." Wittkower and Todd [196] described the various states of mind in these patients: "constructive resignation and indifference, depression and anxiety, defiance and ultra-cheerfulness, resentment and apathy."

Scattered through the literature, there are numerous reports suggesting that the natural history of tuberculosis is modified under the influence of emotional factors, and Hartz [197] noted that "an individual may react to life situations with an anxiety state or other personal behavior in such a way as to interfere with healthy living, and these reactions may thereby become a most significant factor in the onset and course of clinical tuberculosis."

\section{Psychiatric Comorbidity in Pulmonary Tuberculosis}

5.1. Theoretical Considerations. There have been times when the high incidence of tuberculosis in mental illness was interpreted to mean that perhaps tuberculosis may cause mental 


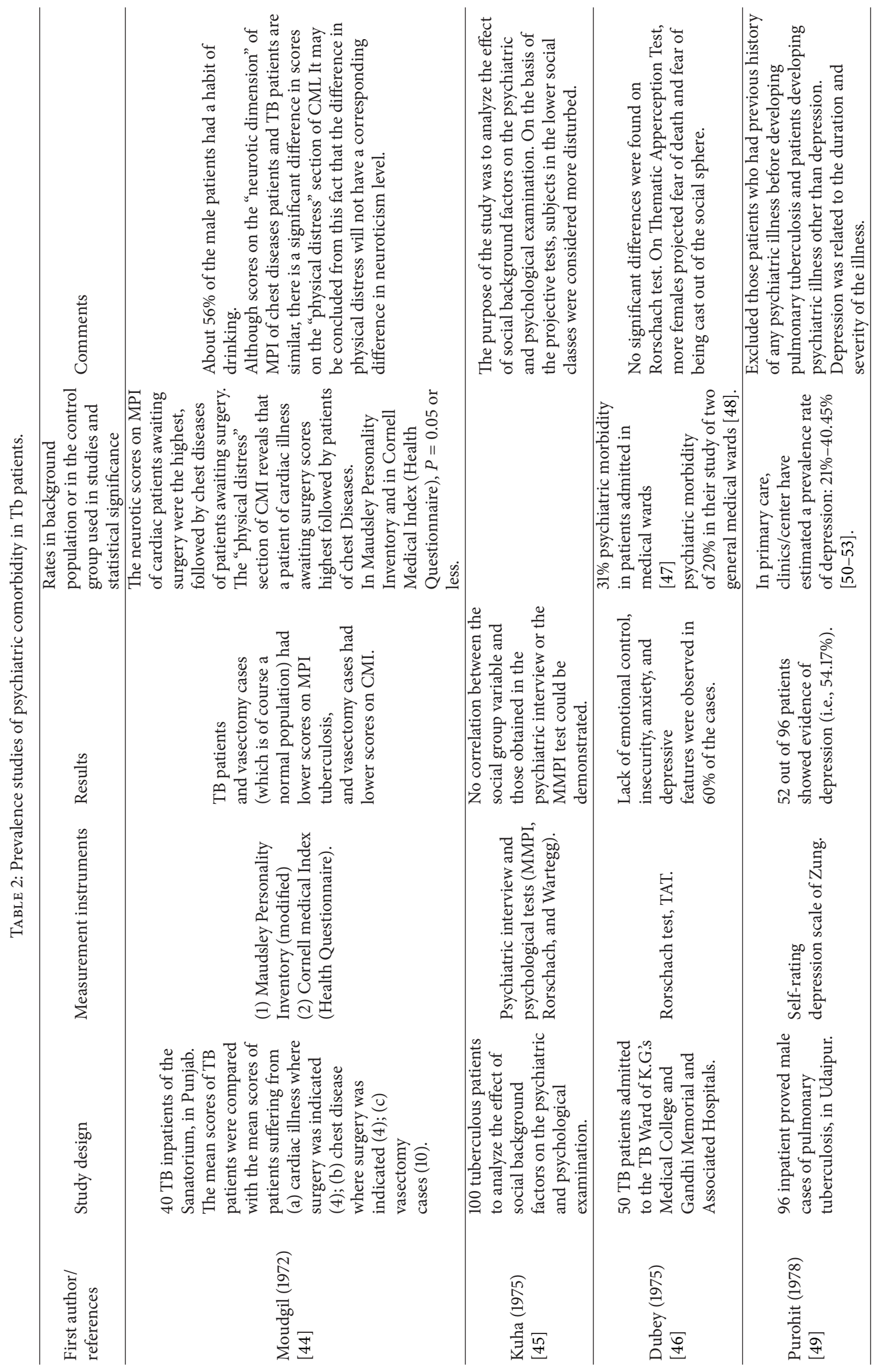




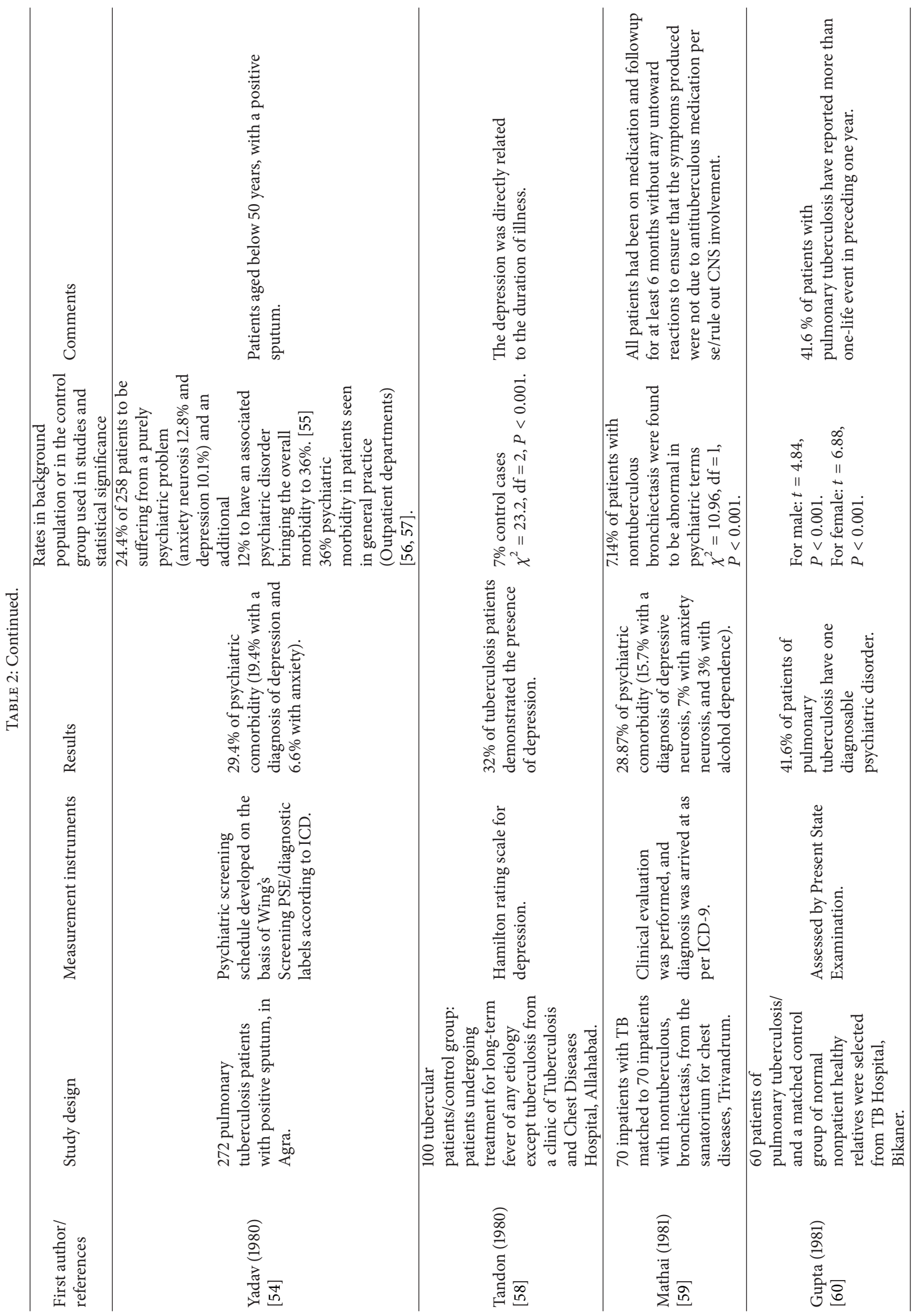




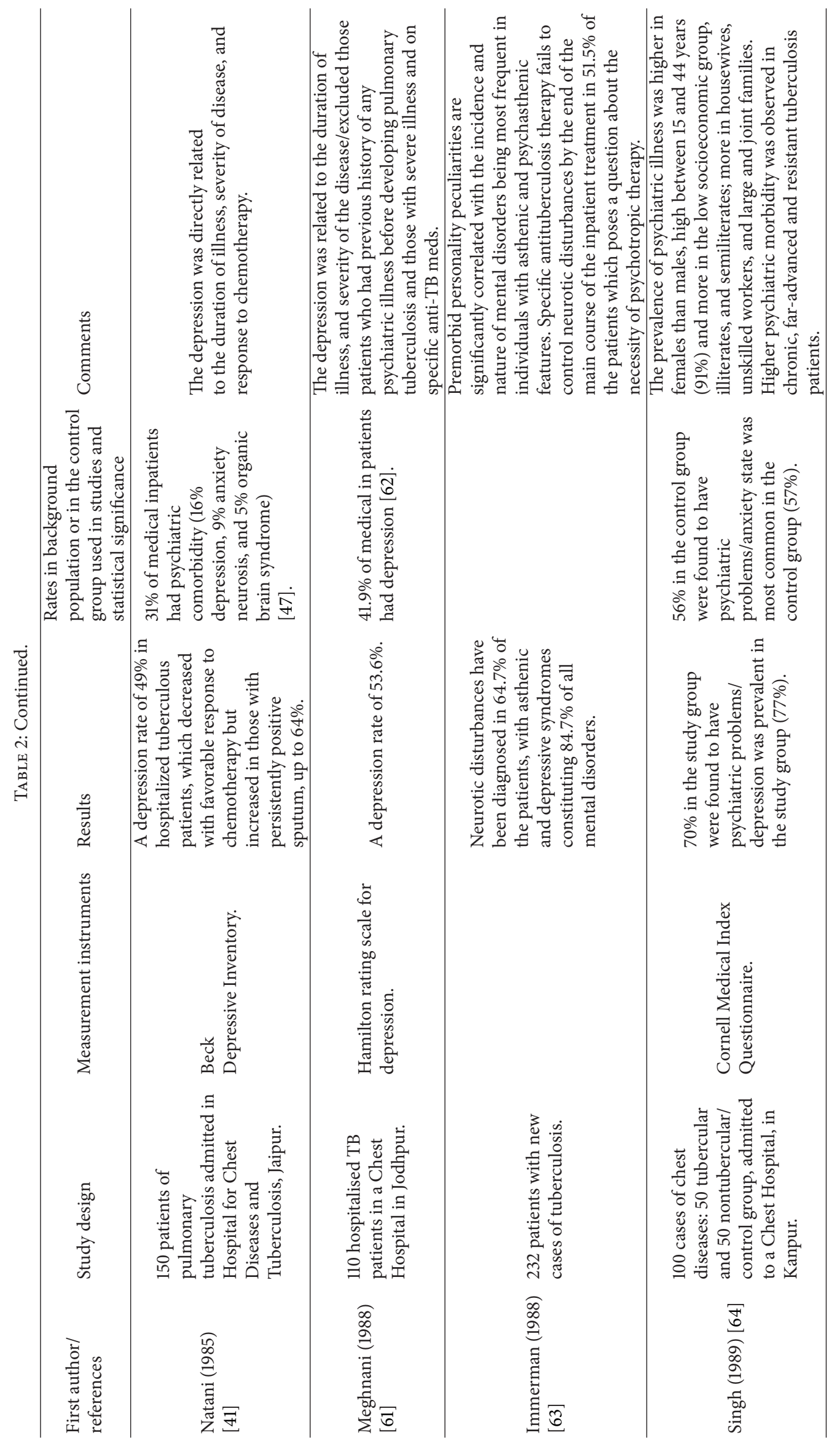




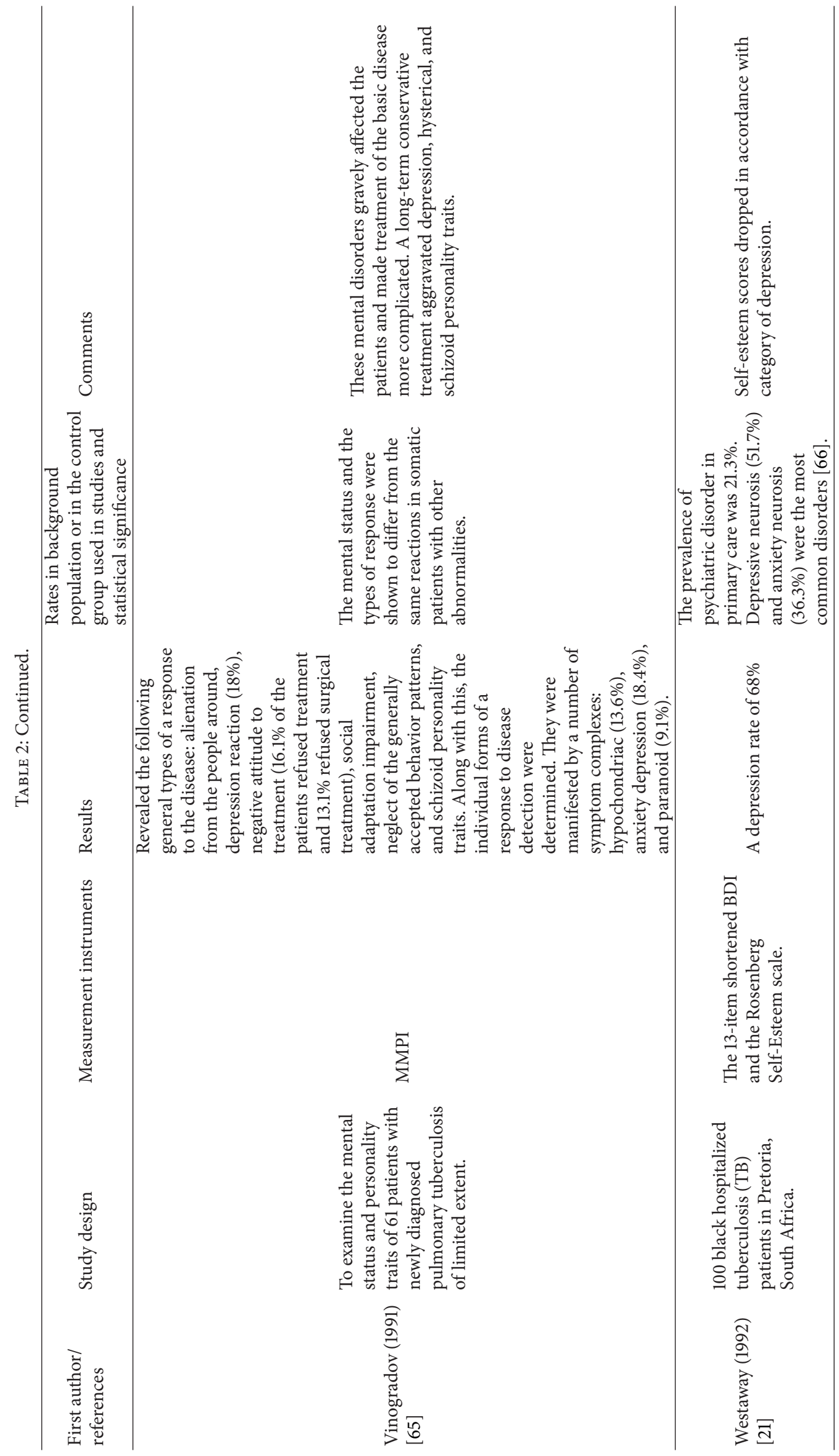




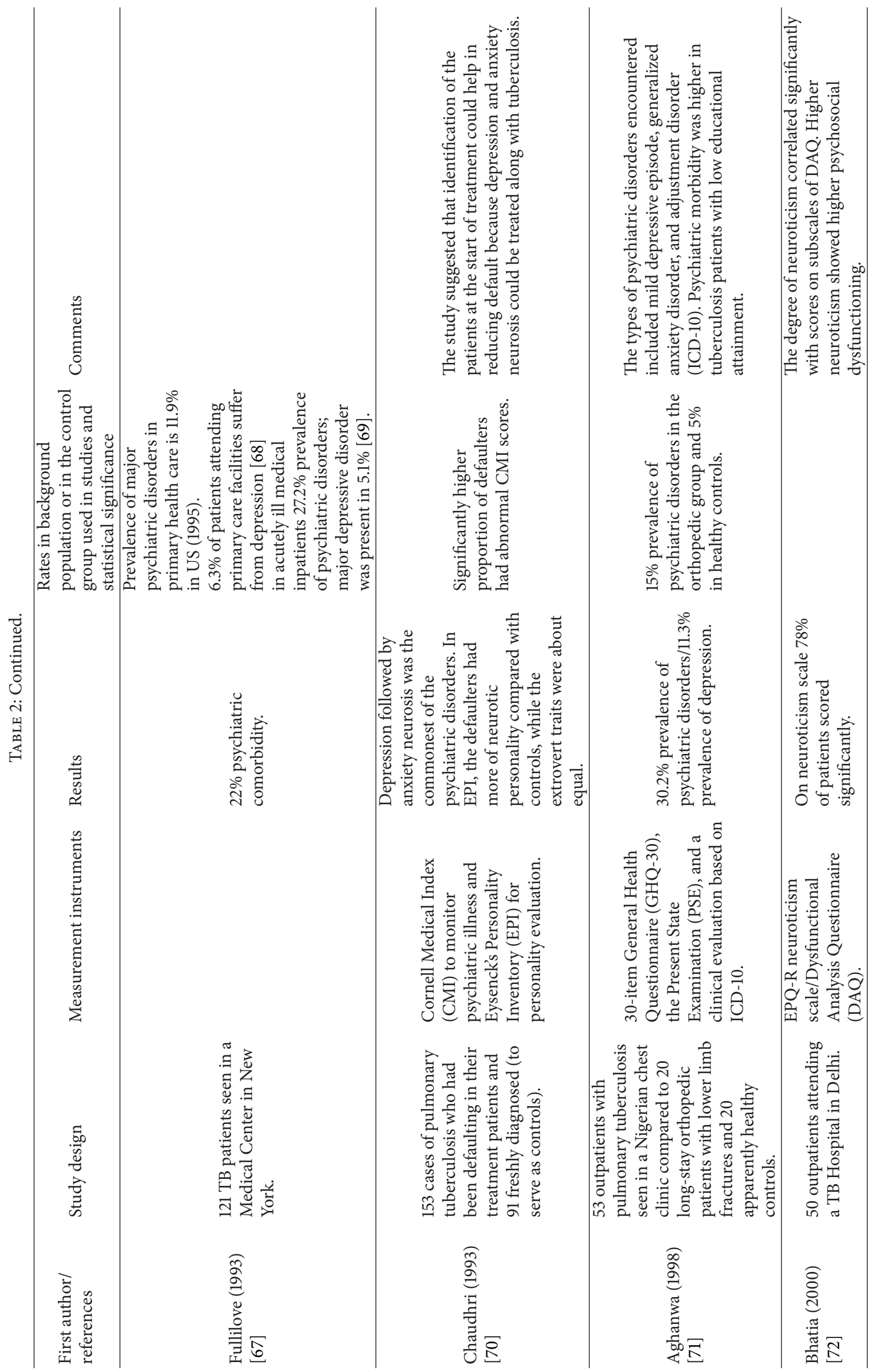




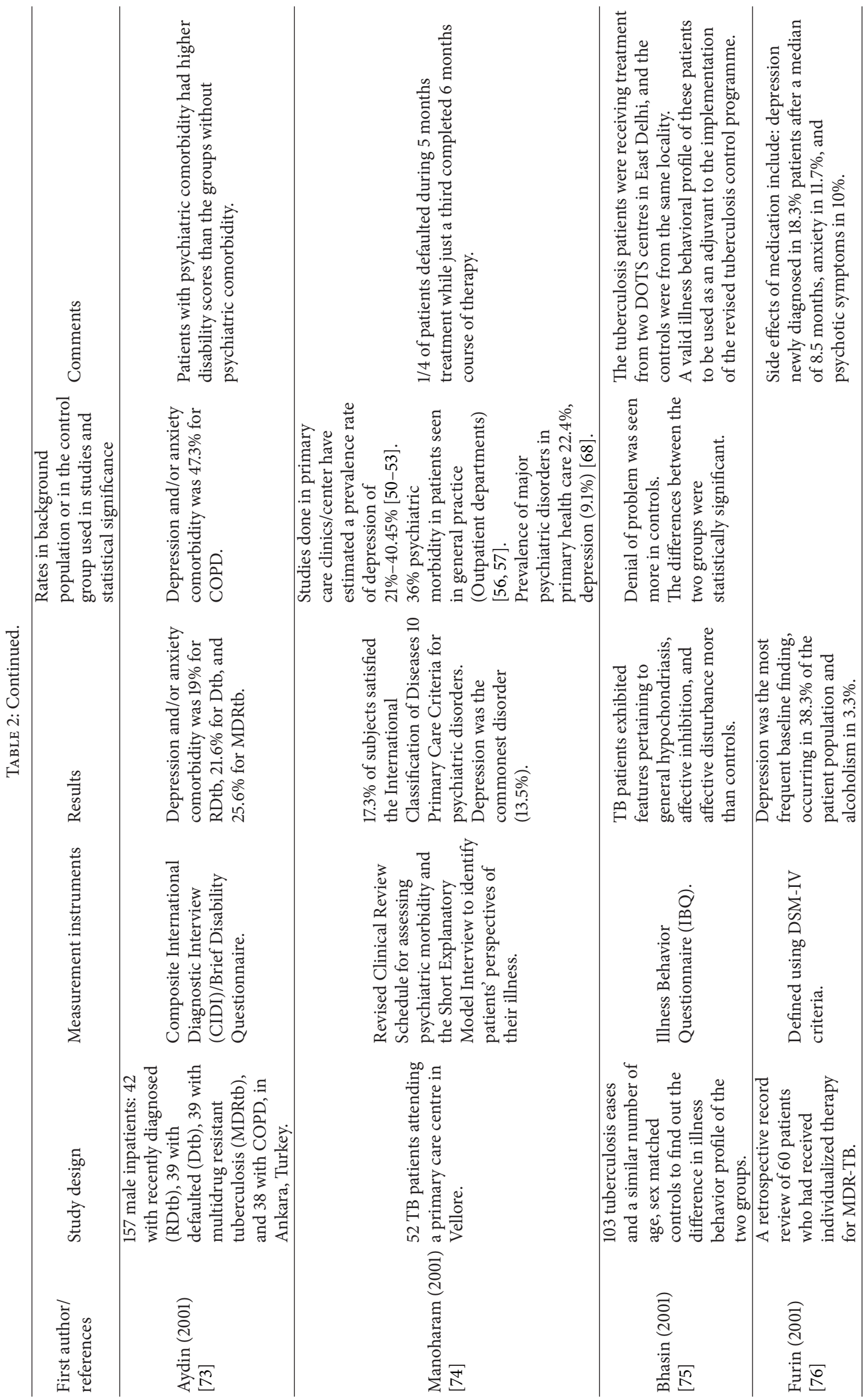




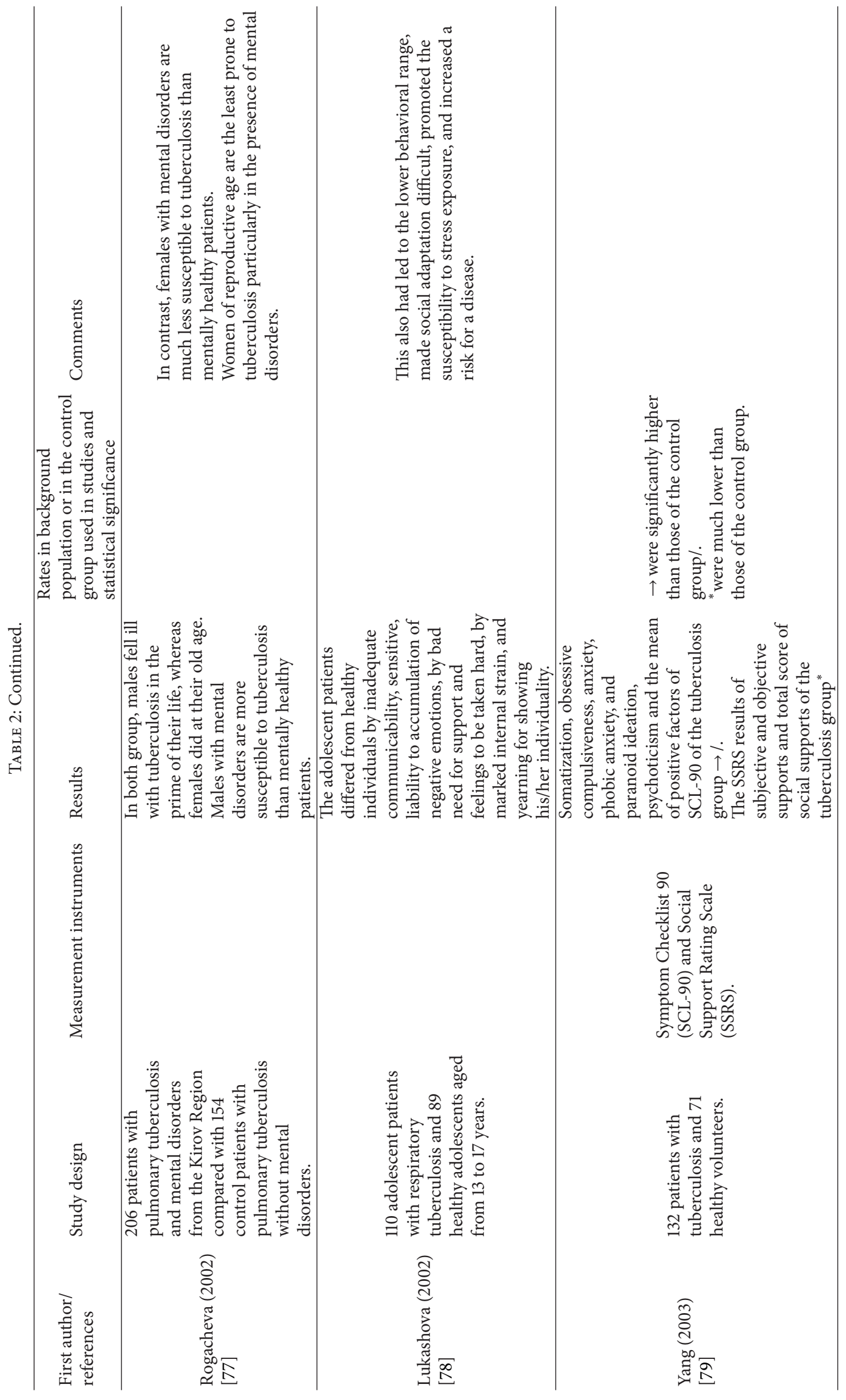




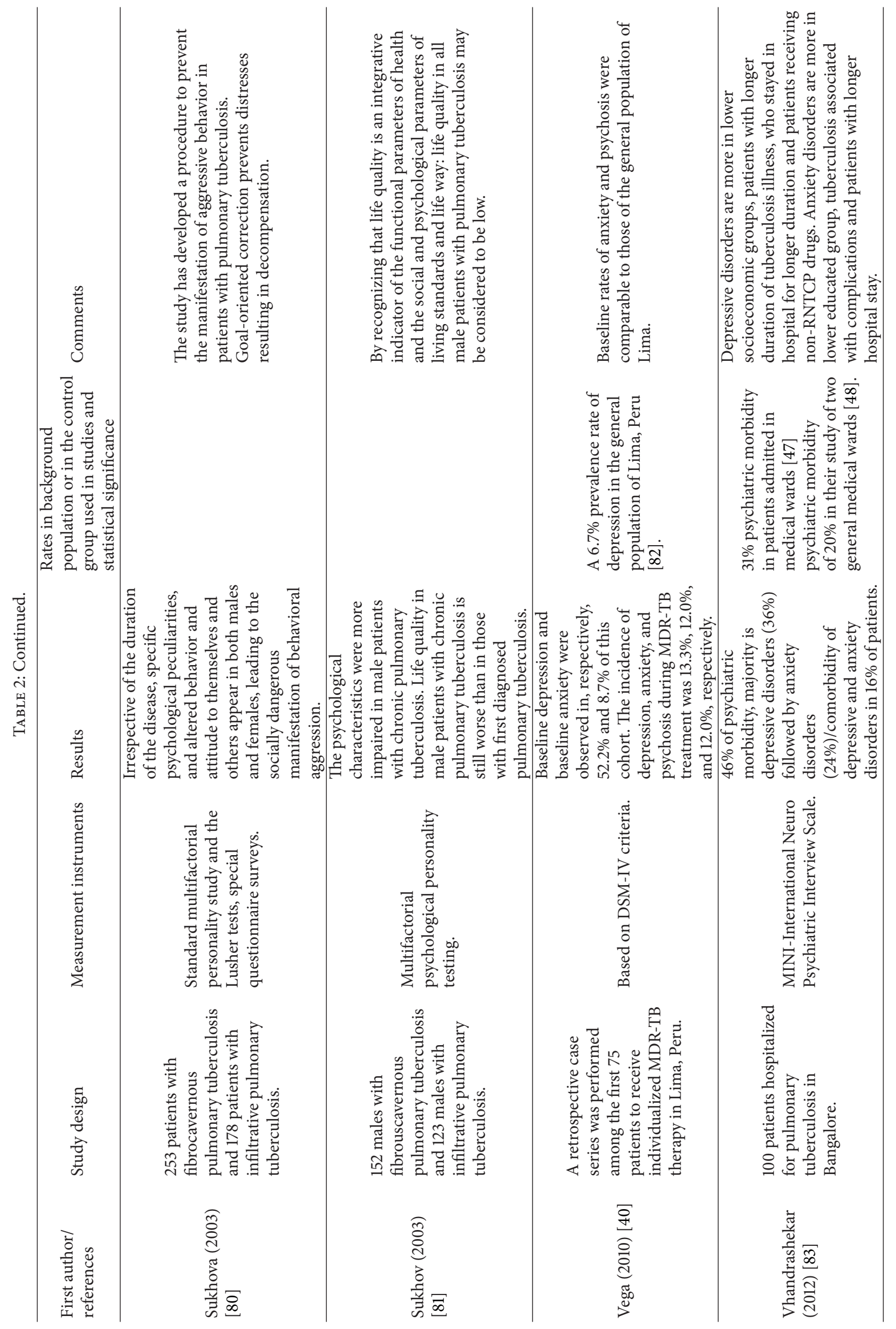




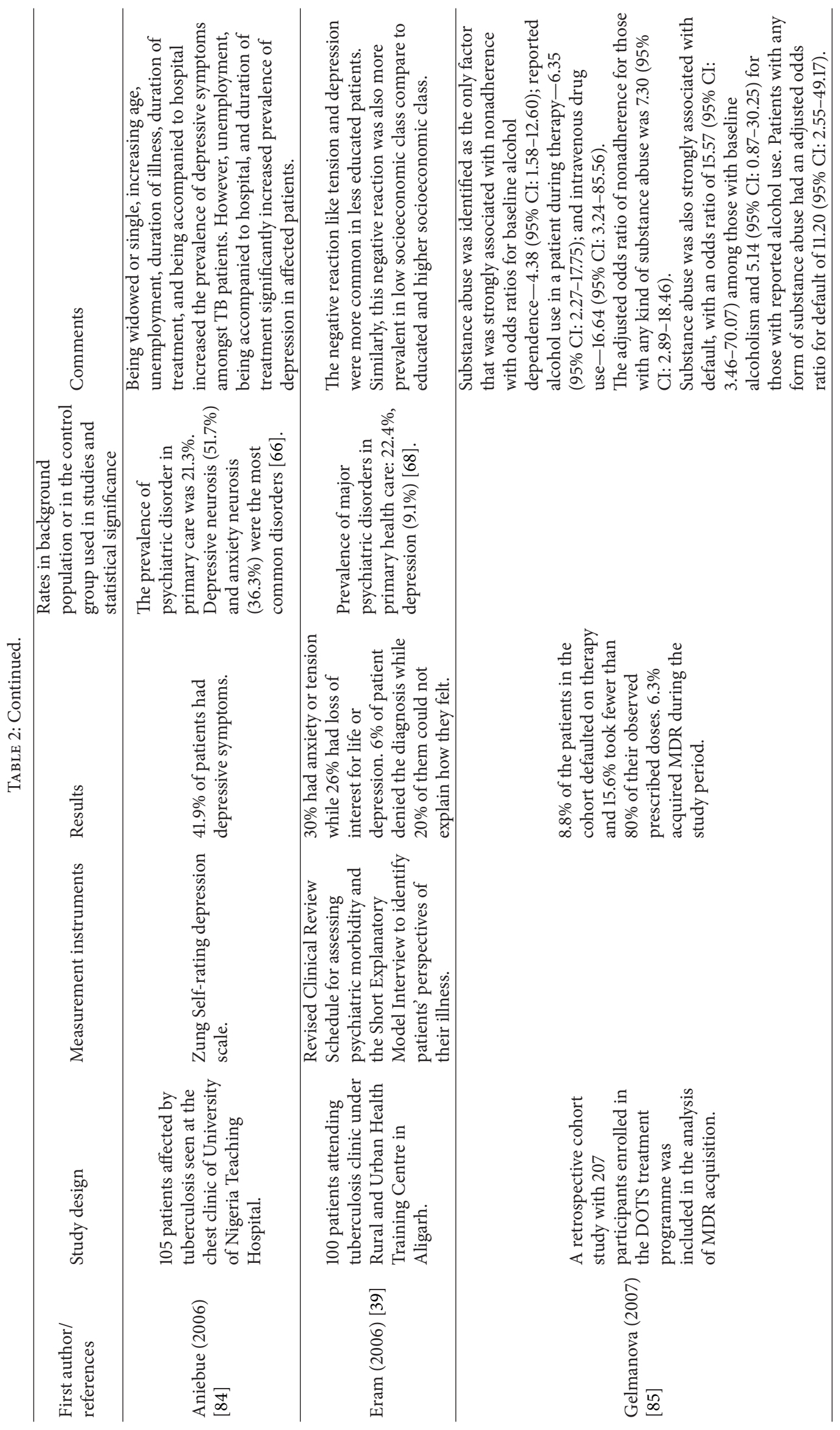




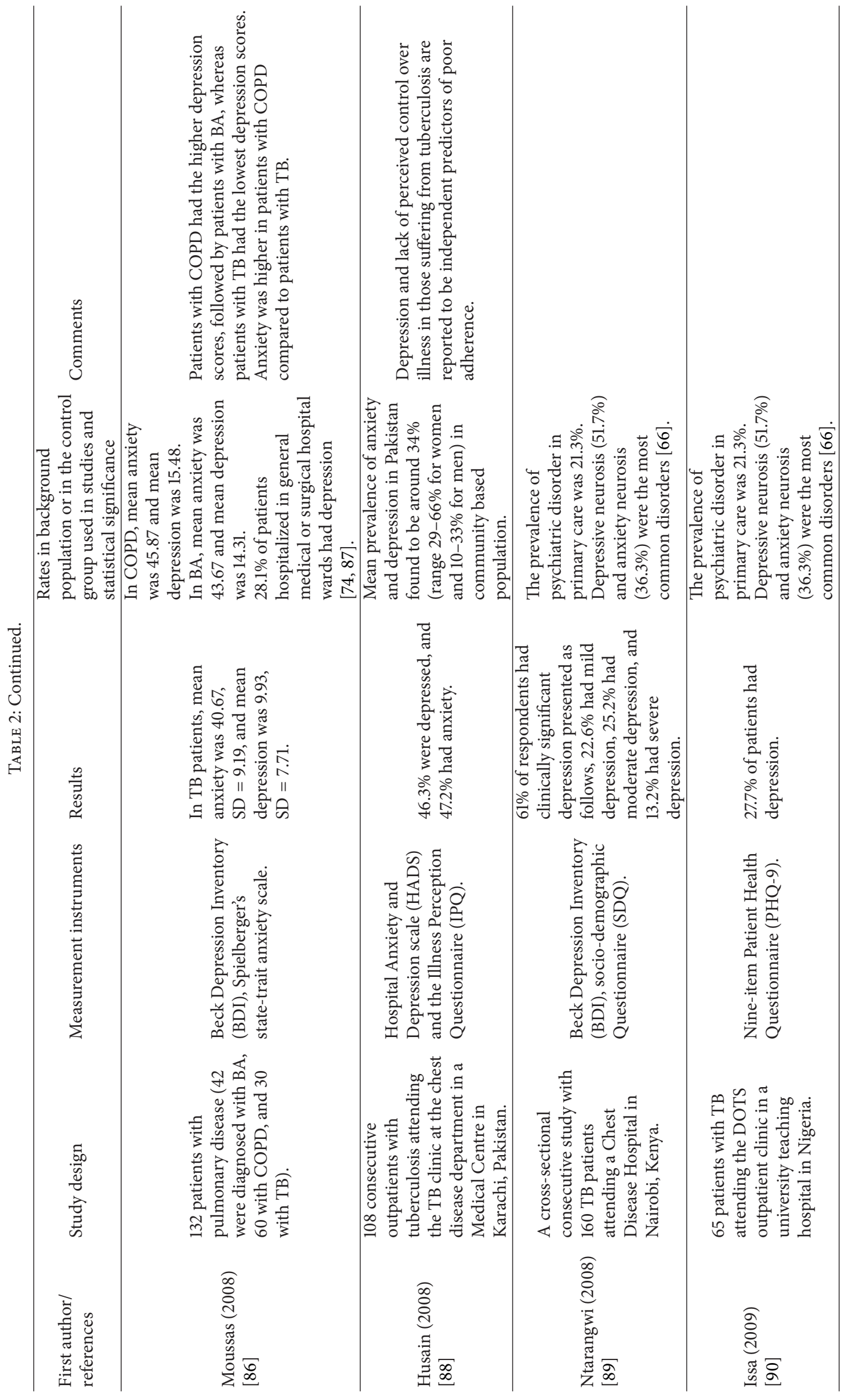




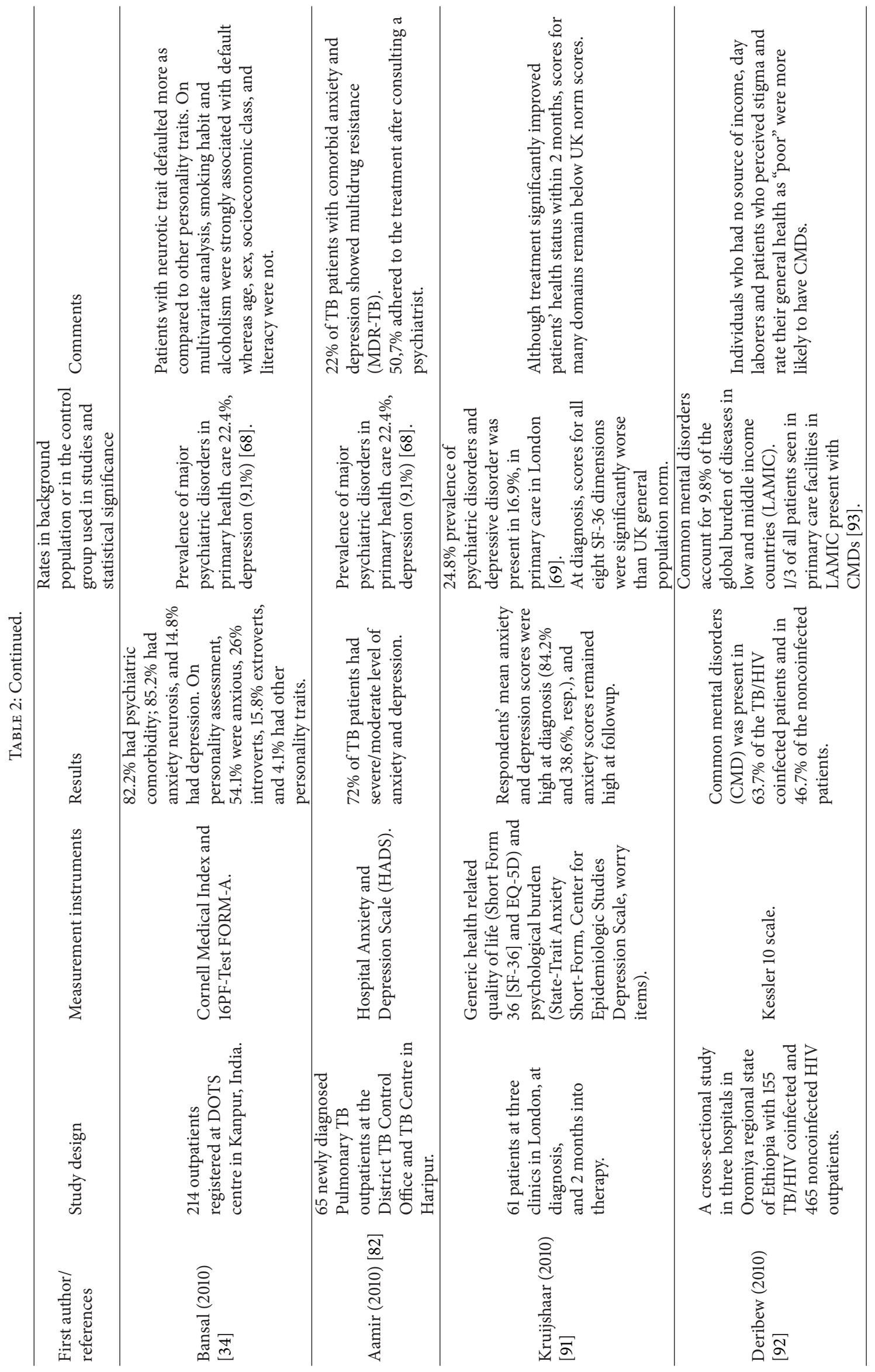




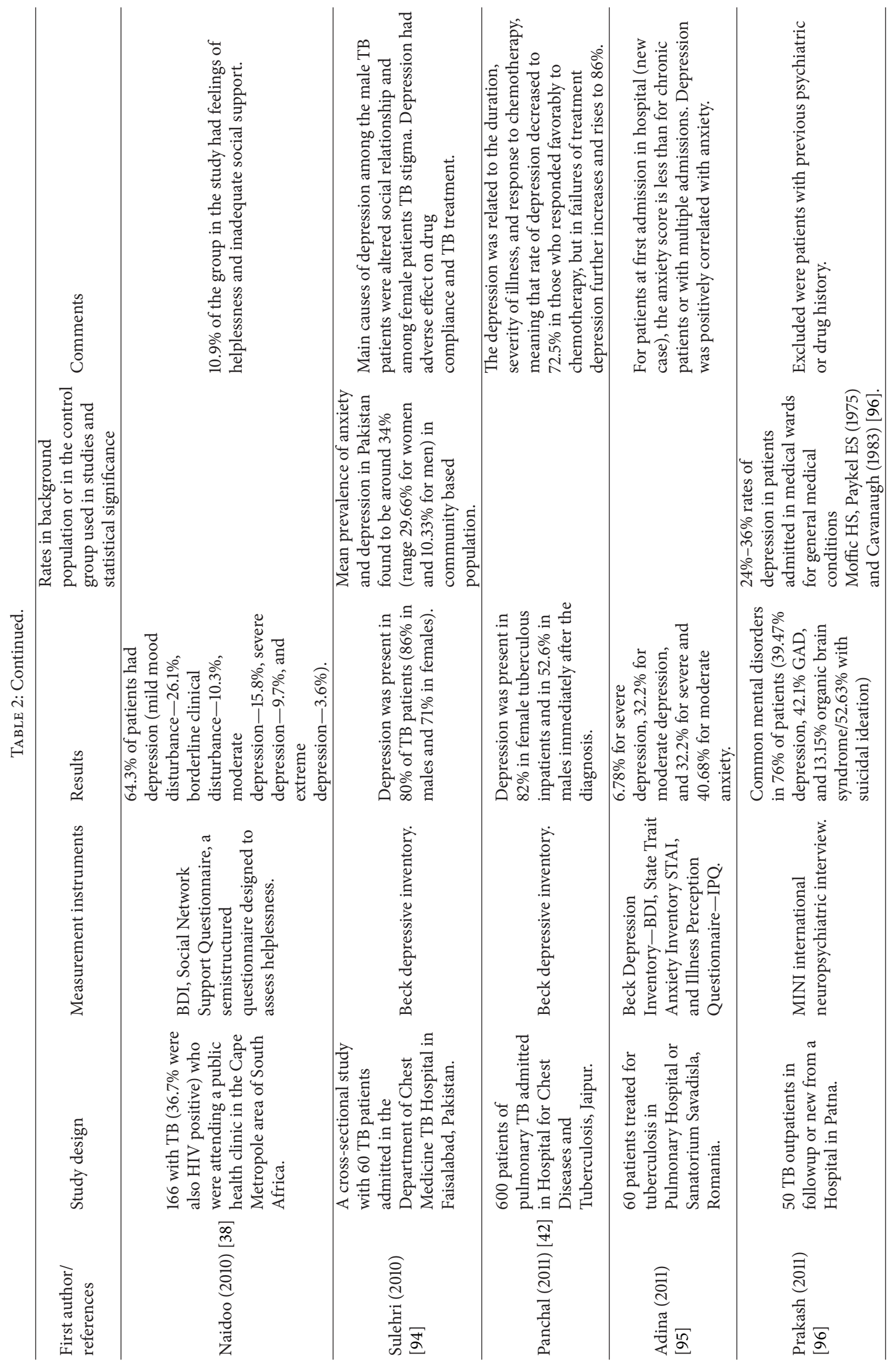




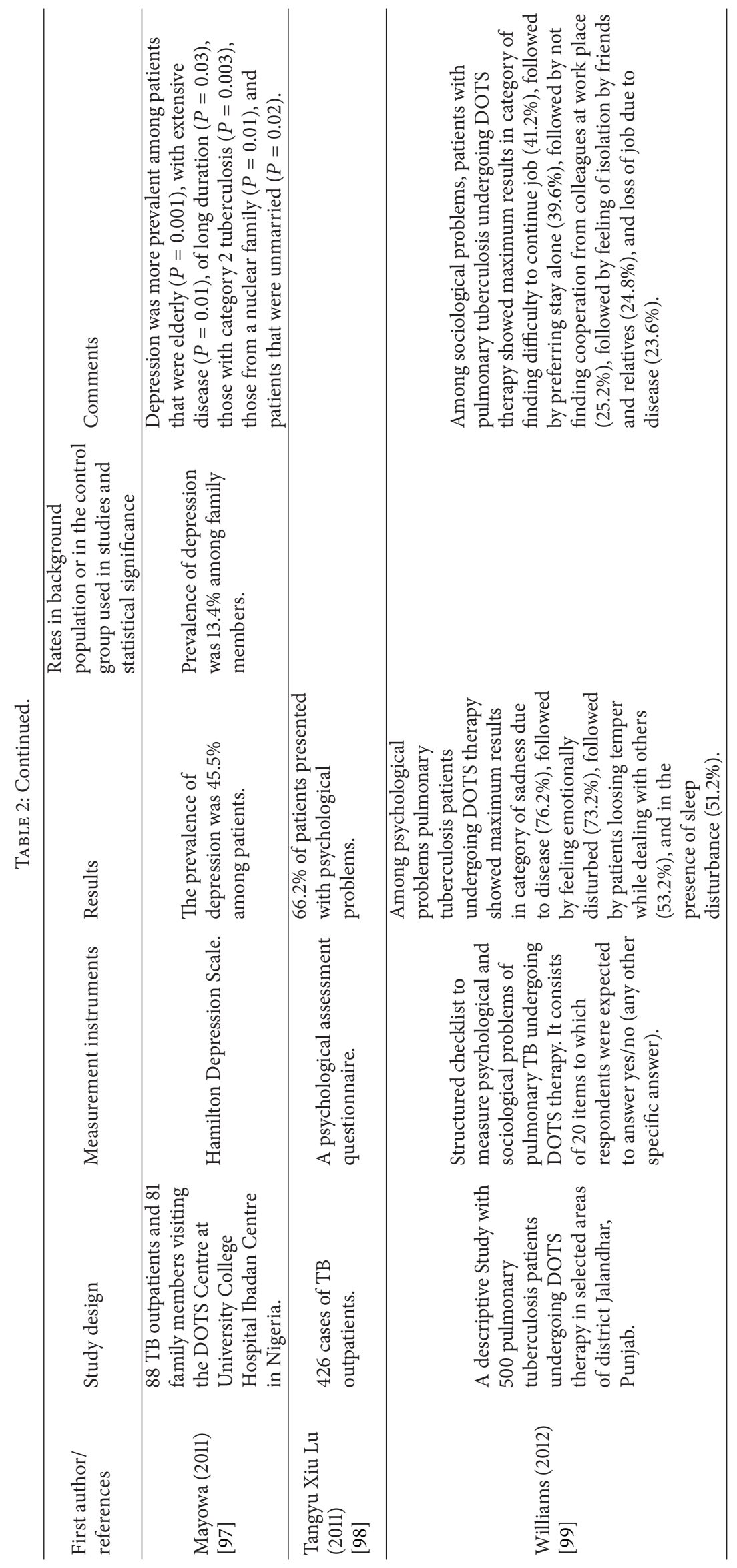




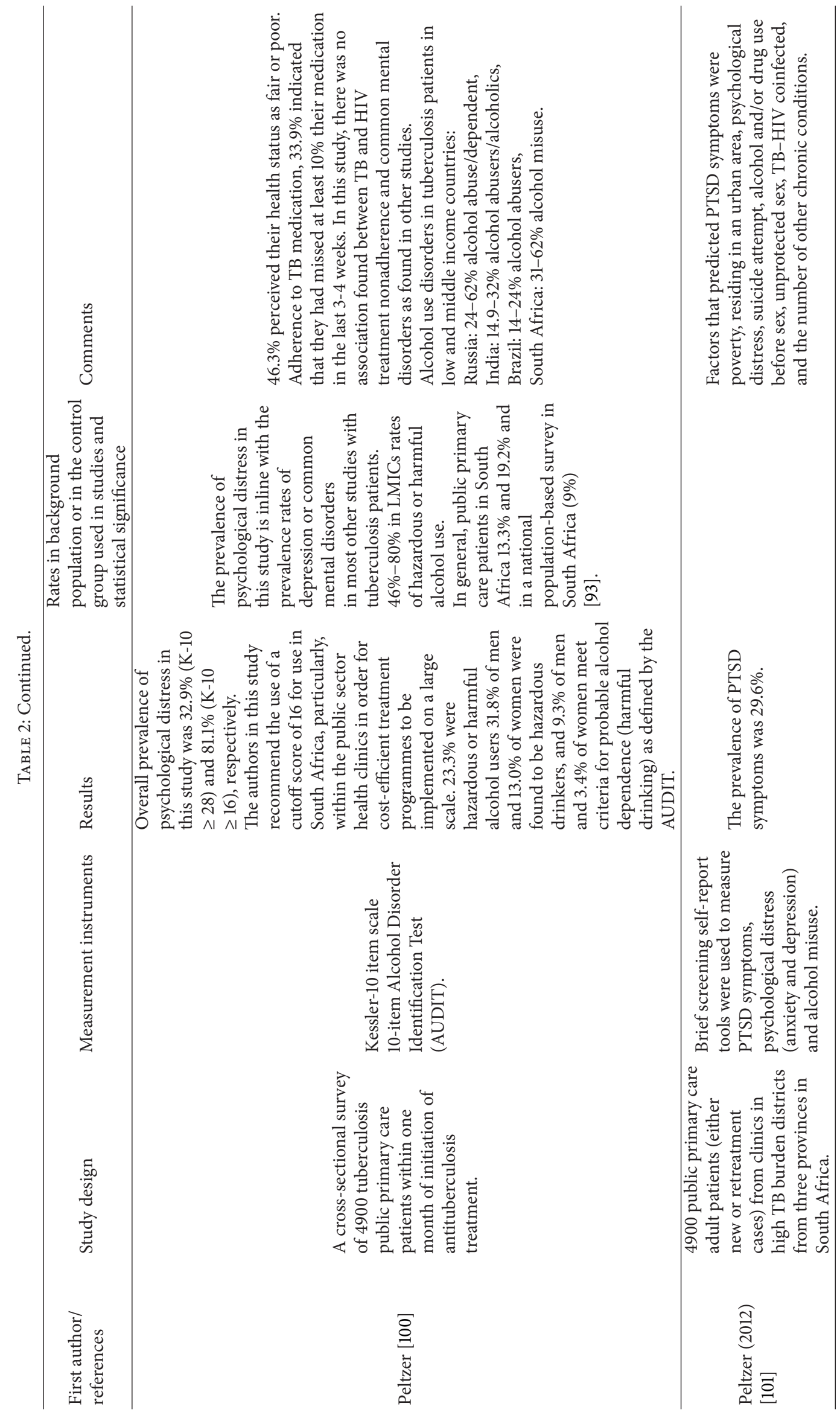


TABLE 3: Prevalence studies of TB comorbidity in patients with chronic mental disorders.

\begin{tabular}{lll}
\hline First author/references & Study design & Results \\
\hline Collins (1956) [102] & $\begin{array}{l}\text { 700 psychiatric inpatients in a } \\
\text { mental hospital. }\end{array}$ & $\begin{array}{l}25 \text { (14 with the diagnosis of } \\
\text { schizophrenia) of them suffered from } \\
\text { pulmonary tuberculosis and were } \\
\text { under surveillance in the sanatorium. }\end{array}$ \\
\hline
\end{tabular}

$\begin{array}{ll}\text { Ohta, } 1988 & \begin{array}{l}\text { 3,251 patients residing in Nagasaki } \\ \text { city and diagnosed as schizophrenia } \\ \text { between } 1960 \text { and } 1978 .\end{array}\end{array}$

The incidence rate of tuberculosis was significantly higher than that of the general population for both male and female schizophrenic patients.

\begin{tabular}{ll}
\hline $\begin{array}{l}\text { Lopez (1994) } \\
{[19]}\end{array}$ & $\begin{array}{l}43 \text { psychiatric patients at a general } \\
\text { hospital at time of discharge. }\end{array}$ \\
\hline & $\begin{array}{l}85 \text { men discharged to community } \\
\text { living by the on-site mental health } \\
\text { program between } 1990 \text { and 1992, in } \\
\text { NY. }\end{array}$ \\
\hline
\end{tabular}

$19 \%$ were PPD positive at time of discharge, with 2 patients requiring a course of isoniazid prophylaxis.

$36.7 \%$ were PPD positive, $11.1 \%$ had inconclusive results, and $6.7 \%$ had active TB.

$17 \%$ had positive results. Of the 20 patients with mood 71 participants in a psychiatric day disorders, 6 patients (30\%) had McQuistion (1997) [20] program of New York City teaching Hospital were given a skin tuberculin test. positive PPD results, accounting for half of all positive findings in the total group. Only 6 (14\%) of 41 patients with psychotic disorders demonstrated positive PPD results.
All HIV-positive men, PPD-positive or inconclusive and all had active TB.

11 of the 12 infected subjects had experienced at least one of seven risk factors of tuberculosis infection (immigration, intravenous drug use, alcohol abuse, history of homelessness, HIV seropositive, known exposure to a person with active TB disease, and currently living in a congregate care setting).

\section{Using a screening questionnaire to} assess the likelihood of TB infection in a random sample of 187 patients seen by a psychiatric emergency service, based on exposure to risk Sanchez (1998) [104] factors (emigration, age over 32 years, male gender, prior psychiatric hospitalizations, injection drug use, alcohol abuse, known exposure to a person with active tubercular disease, and concurrent illness).

Sanchez-Mora (2007) 154 psychiatric patients at a [105] long-term mental institution.

Pirl (2005) [106]
535 patients admitted to a state psychiatric Hospital, in Boston.
$83 \%$ were older than 32 years, $61 \%$ were male, $48 \%$ were immigrants, $44 \%$ had prior psychiatric hospitalizations, $35 \%$ abused alcohol, 35\% were homeless, and $17 \%$ admitted to intravenous drug use.
While these figures did not reach statistical significance, there appeared to be a trend between various risk factors and TB infection.
$4.5 \%$ prevalence rate of tuberculosis.

\begin{tabular}{|c|c|c|c|}
\hline $\begin{array}{l}\text { Pirl (2005) } \\
{[106]}\end{array}$ & $\begin{array}{l}535 \text { patients admitted to a state } \\
\text { psychiatric Hospital, in Boston. }\end{array}$ & $\begin{array}{l}20.2 \% \text { rates of positive } \\
\text { tuberculin compared with } 5 \% \text { screened } \\
\text { positive in the US general population, } \\
z=16,12 P<0.001\end{array}$ & $\begin{array}{l}\text { Independent risk factors for } \\
\text { markers of disease included age, } \\
\text { immigrant status, homelessness, } \\
\text { and history of substance use. The } \\
\text { study confirms the alarmingly high } \\
\text { occurrence of positive tuberculin } \\
\text { skin tests. }\end{array}$ \\
\hline $\begin{array}{l}\text { Hashemi (2009) } \\
\text { [107] }\end{array}$ & $\begin{array}{l}215 \text { psychiatric patients in a } \\
\text { long-term mental institution, in } \\
\text { Hamedan, Iran. }\end{array}$ & $\begin{array}{l}28.8 \% \text { rate of positive PPD results, } \\
40.3 \% \text { of them had radiographic } \\
\text { evidences of inactive pulmonary } \\
\text { tuberculosis. }\end{array}$ & $\begin{array}{l}\text { In Iran, higher prevalence rates } \\
\text { were found in prisoners, drug } \\
\text { abusers, and hospital employees } \\
\text { ( } 50 \%, 66.7 \% \text {, and } 36.2 \% \text {, resp.); } \\
\text { however, they imply lower } \\
\text { prevalence rates (1.6-14.2\%) in } \\
\text { low-risk groups. }\end{array}$ \\
\hline $\begin{array}{l}\text { Cavanaugh (2012) } \\
{[108]}\end{array}$ & $\begin{array}{l}75 \text { residents exposed to TB at the } \\
\text { assisted living facility for adults with } \\
\text { mental illness, in Florida. }\end{array}$ & $\begin{array}{l}88 \% \text { were infected. By comparison, the } \\
\text { prevalence of latent TB infection } \\
\text { among reported contacts of } \\
\text { pulmonary TB patients with positive } \\
\text { sputum smears in the United States has } \\
\text { been estimated at } 20 \%-30 \% \text {. }\end{array}$ & $\begin{array}{l}\text { An elevated risk for TB infection } \\
\text { among adults with mental illness } \\
\text { and a risk for sustained } \\
\text { transmission when they inhabit } \\
\text { crowded congregate settings. }\end{array}$ \\
\hline
\end{tabular}


TABLE 4: Studies reporting patients' psychological reactions and disease perceptions about TB.

\begin{tabular}{|c|c|}
\hline $\begin{array}{l}\text { First author/ } \\
\text { references }\end{array}$ & Reports from studies \\
\hline Eram [39] & $\begin{array}{l}\text { Tuberculosis is a disease both of individual and society and patients' first reactions to the diagnosis were tension/anxiety } \\
(30 \%), \text { loss of interest/depression }(26 \%) \text {, denial (6\%), could not explain how they felt ( } 20 \%) \text {, and only } 18 \% \text { were hopeful } \\
\text { of cure. }\end{array}$ \\
\hline Rajeswari [109] & The initial reaction of patients to the disclosure of the diagnosis was worry (50\%) and suicidal thoughts (9\%). \\
\hline Deribew [92] & $\begin{array}{l}\text { People with perceived stigma may have a low self-image and be socially isolated which may predispose them to common } \\
\text { mental disorders. }\end{array}$ \\
\hline $\begin{array}{l}\text { Jaggarajamma } \\
{[110]}\end{array}$ & $\begin{array}{l}\text { Perceived stigma which refers to the fear of discrimination or acceptability was higher than enacted stigma, which refers } \\
\text { to actual discrimination or acceptability. }\end{array}$ \\
\hline $\begin{array}{l}\text { Courtwright } \\
\text { [111] }\end{array}$ & $\begin{array}{l}\text { The most common cause of TB stigma is the risk of transmission from TB infected individuals to susceptible } \\
\text { community members but also because of its association with HIV, poverty, low social class, malnutrition, or disreputable } \\
\text { behavior. Also, TB stigma had a more significant impact on women and on poor or less-educated community members, } \\
\text { which is especially concerning given that these groups are often at higher risk for health disparities [112]. TB stigma may, } \\
\text { therefore, worsen preexisting gender- and class-based health disparities, and it is perceived to increase TB diagnostic } \\
\text { delay and treatment nonadherence [37,113]. }\end{array}$ \\
\hline Naidoo [38] & $\begin{array}{l}\text { People who have a lifelong or infectious disease and who have limited social, psychological, and economic resources find } \\
\text { it extremely difficult to maintain a reasonable quality of life and that helplessness [114] and depression have a negative } \\
\text { influence on adherence to treatment. }\end{array}$ \\
\hline Marra [115] & $\begin{array}{l}\text { There are numerous aspects of active TB that may lead to a reduction in the quality of life, such as prolonged therapy } \\
\text { with multiple, potentially toxic drugs that can lead to adverse reactions in a significant number of patients. Also, there is } \\
\text { considerable social stigma associated with active TB leaving the individual feeling shunned and isolated from their } \\
\text { friends and families, and there is a lack of knowledge regarding the disease process and its treatment which may } \\
\text { contribute to feelings of helplessness and anxiety. }\end{array}$ \\
\hline
\end{tabular}

illness or that mental illness forms a strong predisposition to tuberculosis [198].

The literature suggests the mutual influence and relationship between physical and mental illness, and many studies report the nature and prevalence of comorbid physical illness with severe mental disorders [199]. Research in this direction is mainly concerned with studying physical morbidity among psychiatrically ill individuals [200], but studies to delineate psychiatric profile of physically ill persons [201,202] have also received attention.

Medical illness and chronic disease create multiple burdens for patients, including the necessity to deal with pain, suffering, reduced quality of life, premature mortality, financial costs, and familial emotional trauma [110]. The risk factors for mental health problems are complex [203]. Presence of medical illness [204], stigma, and discrimination [92] are major determinants of mental disorders, especially mood and anxiety disorders. Usually, the more serious the somatic disease, the more probable will be, to be accompanied by mood and/or anxiety symptoms of variable severity [86]; conditions arising after the somatic disease is diagnosed. Failure to manage such mental health problems increases the patients' probability of suffering from complications, even lethal.

The lifetime prevalence of mood disorder in patients with chronic disease is from $8.9 \%$ to $12.9 \%$, with a 6 -month prevalence of $5.8 \%$ to $9.4 \%[205,206]$. According to findings from worldwide research, $20 \%$ of patients with somatic disease suffer from major depression [207, 208].
In patients with pulmonary disease in particular, functionality may be severely impaired due to chronic psychogenic and somatic pain [209], frequent hospital admissions, and dependency from medical and nursing personnel. The observed higher prevalence of depression and anxiety in patients with chronic pulmonary disease [210]_compared to other chronic diseases-may be explained within this context.

The reasons for the frequent cooccurrence of psychiatric disorders and medical illnesses could be that the first represents reactions to illnesses and treatment or that they are a direct physiological consequence of the illness or complications of treatments (INH-induced psychosis) [83, 134].

Also, psychiatric disorders may coincide with medical illnesses, without being etiologically related to them, but they complicate the diagnosis and management and can alter their course. For diagnostic purposes, it is often difficult to determine if the vegetative symptoms of depression or somatic symptoms of anxiety are evidences of the psychiatric disorder or symptoms of medical disease, or both.

Another reason for the frequent comorbidity is that there are commonly shared risk factors [19] for the development of a variety of psychiatric and medical disorders (smoking [211], low socioeconomic status [93], etc.).

Tuberculosis is a classic example of a disease with both medical and social dimensions, characterized by its close relation to poor socioeconomic conditions [110]. Increased risk [1, 105] of acquiring active disease occurs with alcoholism, smoking, intravenous drug abuse, diabetes mellitus, 
TABLE 5: Psychiatric disorders in patients receiving TB medications.

\begin{tabular}{|c|c|c|c|}
\hline Anti-TB drug & Reported adverse event & Frequency of event & References \\
\hline $\begin{array}{l}\text { Isoniazid (INH) or } \\
\text { iproniazid (IPH) }\end{array}$ & $\begin{array}{l}\text { Toxic psychoses developed while under treatment with } \\
\text { isoniazid or iproniazid in combination with other } \\
\text { antituberculous drugs }\end{array}$ & $\begin{array}{l}5 \text { cases seen at Charity Hospital of } \\
\text { Louisiana, at New Orleans }\end{array}$ & {$[116]$} \\
\hline Cycloserine & $\begin{array}{l}\text { Showed some type of neurologic or psychiatric } \\
\text { disturbance of varying severity }\end{array}$ & $\begin{array}{l}15 \text { out of } 30 \text { TB patients } \\
6 \text { showed severe disturbance of function, } \\
\text { either manifested by mounting signs of } \\
\text { central nervous system instability (grand } \\
\text { mal convulsions) or in borderline or } \\
\text { outright psychosis. }\end{array}$ & {$[117]$} \\
\hline Isoniazid and ethambutol & $\begin{array}{l}\text { Peripheral neuropathy is associated with the use of } \\
\text { isoniazid }\end{array}$ & $\begin{array}{l}\text { In approximately } 17 \% \text { of patients using } \\
\text { doses of } 300 \mathrm{mg} \text { daily and } \\
\text { lower frequency to the use of ethambutol }\end{array}$ & {$[118]$} \\
\hline Isoniazid and ethambutol & $\begin{array}{l}\text { The optic neuritis manifests with reduced visual field or } \\
\text { acuity or color vision }\end{array}$ & $\begin{array}{l}\text { Uncommon during the use of isoniazid } \\
\text { and ethambutol/is related to generally at } \\
\text { high doses or prolonged use }\end{array}$ & {$[118]$} \\
\hline Isoniazid & $\begin{array}{l}\text { The behavioral disorders, changes in the rhythm of } \\
\text { sleep, reduced memory, and psychosis have been } \\
\text { described for the use of isoniazid. Seizures and coma } \\
\text { are described by the excessive intake of isoniazid. }\end{array}$ & $\begin{array}{l}\text { Alcoholism, diabetes mellitus, } \\
\text { malnutrition, and uremia are all } \\
\text { predisposing factors for neurological and } \\
\text { psychiatric disorders listed here. }\end{array}$ & {$[118]$} \\
\hline streptomycin & $\begin{array}{l}\text { The toxicity acoustic (or vestibular) is a complication } \\
\text { related to the use of streptomycin. }\end{array}$ & & {$[118]$} \\
\hline Isoniazid & $\begin{array}{l}\text { Minor adverse effects. } \\
\text { Changes in behavior: headache, insomnia, euphoria, } \\
\text { agitation, anxiety, and somnolence can occur in } \\
\text { patients receiving isoniazid }\end{array}$ & & {$[119]$} \\
\hline Isoniazid & $\begin{array}{l}\text { Major adverse effects: } \\
\text { Psychosis, convulsive seizures, mental confusion, and } \\
\text { coma. Attempted suicides have been reported to occur } \\
\text { among patients using isoniazid }\end{array}$ & $\begin{array}{l}\text { In patients receiving isoniazid, } \\
\text { neurological and psychiatric } \\
\text { manifestations are less common, more } \\
\text { severe, and often difficult to diagnose. } \\
\text { The differential diagnosis with } \\
\text { tuberculous meningitis and hepatic } \\
\text { encephalopathy should be established. }\end{array}$ & {$[119]$} \\
\hline Isoniazid & $\begin{array}{l}\text { Out of the five psychotics, three were manic, and two } \\
\text { were depressive. } \\
\text { Among the six neurotics, three were depressive and one } \\
\text { each of anxiety, obsessive compulsive, and phobic } \\
\text { neurosis }\end{array}$ & $\begin{array}{l}11 \text { (five psychotics and six neurotics) out } \\
\text { of } 732 \text { in patients of the hospital for } \\
\text { tuberculosis and chest diseases, } \\
\text { symptoms were nondose related }\end{array}$ & {$[120]$} \\
\hline Isoniazid & INH-induced psychosis & $\begin{array}{l}8 \text { cases of INH-induced psychosis out of } \\
4960 \text { hospitalised patients of pulmonary } \\
\text { tuberculosis receiving INH }\end{array}$ & {$[121]$} \\
\hline Isoniazid & $\begin{array}{l}\text { Toxic psychosis as a psychiatric side effect during } \\
\text { antituberculosis therapy occurred when isoniazid was } \\
\text { given in dose ranging from } 2.6 \text { milligrams to } 4.5 \\
\text { milligrams/kg bodyweight, over a period of eight to } \\
\text { thirty six weeks. }\end{array}$ & $\begin{array}{l}\text { Five cases developing psychosis while } \\
\text { receiving isoniazid that presented with } \\
\text { excessive argumentation, mental } \\
\text { depression, euphoria, grandiose ideas, } \\
\text { and complex delusions; none of these } \\
\text { patients had any previous history of } \\
\text { mental illness. }\end{array}$ & {$[122]$} \\
\hline Ethambutol and isoniazid & $\begin{array}{l}\text { Concomitant occurrence of INH- and EMB-induced } \\
\text { psychosis in a single individual }\end{array}$ & $\begin{array}{l}\text { A case report: an extremely uncommon } \\
\text { event }\end{array}$ & {$[123]$} \\
\hline Isoniazid & $\begin{array}{l}\text { Symptoms of restlessness, irritability, emotional } \\
\text { instability, agitation, apprehension, and fluctuation in } \\
\text { behavior after isoniazid therapy }\end{array}$ & A case report & {$[124]$} \\
\hline
\end{tabular}


TABle 5: Continued.

\begin{tabular}{|c|c|c|c|}
\hline Anti-TB drug & Reported adverse event & Frequency of event & References \\
\hline Isoniazid & $\begin{array}{l}\text { A case of isoniazid psychosis in a } 74 \text {-year-old, who } \\
\text { developed restlessness, irritability, aimless activity, and } \\
\text { incongruous actions } 10 \text { days after starting isoniazid } \\
\text { therapy }\end{array}$ & A case report & {$[125]$} \\
\hline Isoniazid & $\begin{array}{l}\text { A case of isoniazid-induced psychosis with disturbed } \\
\text { sleep, restlessness, and abnormal behavior }\end{array}$ & A case report & {$[126]$} \\
\hline Ethambutol & $\begin{array}{l}\text { A } 40 \text {-year-old man with advanced HIV infection and } \\
\text { mycobacterium avium complex infection experienced } \\
\text { rapid cognitive decline after commencement of } \\
\text { ethambutol, and symptoms fully resolved with cessation }\end{array}$ & A case report & [127] \\
\hline Ethambutol & $\begin{array}{l}\text { A case of a 51-year-old man with suspected tuberculosis } \\
\text { (TB) pleurisy. An anti-TB trial with INH, rifampicin, } \\
\text { and EMB was given initially. Dizziness, disorientation, } \\
\text { and auditory and visual hallucinations developed after } \\
\text { seven days of therapy. When the patient was challenged } \\
\text { with EMB, the same psychiatric symptoms recurred but } \\
\text { resolved again after discontinuation of } \\
\text { EMB. }\end{array}$ & A case report & {$[128]$} \\
\hline $\begin{array}{l}\text { The neurological } \\
\text { manifestations and } \\
\text { toxicities of } 12 \\
\text { antituberculosis drugs } \\
\text { (isoniazid, rifampicin } \\
\text { (rifampin), ethambutol, } \\
\text { p-aminosalicylic acid, } \\
\text { pyrazinamide, } \\
\text { streptomycin, kanamycin, } \\
\text { ethionamide, cycloserine, } \\
\text { capreomycin, viomycin, } \\
\text { and thiacetazone) are } \\
\text { reviewed }\end{array}$ & $\begin{array}{l}\text { In the Boston Collaborative Drug Surveillance Program } \\
\text { performed in } 1974 . \\
\text { With rifampicin neurological complications have been } \\
\text { observed infrequently, isoniazid is associated with a } \\
\text { large number of accidental and intentional poisonings. }\end{array}$ & $\begin{array}{l}\text { More than } 35 \% \text { of adverse effects } \\
\text { associated with INH were psychiatric in } \\
\text { nature, with an incidence of } 1.9 \% \text {. } \\
\text { Adverse reactions to cycloserine are } \\
\text { mainly dose related with neurological } \\
\text { and psychiatric syndromes noted in up to } \\
50 \% \text { of patients. } \\
\text { The highest incidence has been observed } \\
\text { with Southwestern American Indians in } \\
\text { which this agent was involved in } 7 \% \text { of all } \\
\text { suicide attempts and } 19 \% \text { of the suicide } \\
\text { deaths. }\end{array}$ & [129] \\
\hline Isoniazid & $\begin{array}{l}\text { In Peru, severe psychiatric syndromes associated with } \\
\text { INH }\end{array}$ & $\begin{array}{l}\text { Occurred in approximately } 1.0 \% \text { of } \\
\text { tuberculosis cases between } 1991 \text { and } 1999\end{array}$ & {$[130]$} \\
\hline Isoniazid & $\begin{array}{l}\text { All case reports describing isoniazid-associated } \\
\text { psychosis were reviewed. } \\
\text { Studies were evaluated for the use of isoniazid, } \\
\text { symptoms of psychosis, onset of symptoms, and dosage } \\
\text { of isoniazid. } \\
\text { The most common psychiatric symptoms associated } \\
\text { with INH were delusions, generally presenting after } \\
\text { approximately } 4 \text { weeks of taking the drug, and among } \\
\text { patients of an average age of } 35 \text { years (range } 17-53 \text { ). } \\
\text { They summarize risk factors as receiving a dose above } \\
5 \text { mg/kg; age } 50 \text { years or older; comorbid disease } \\
\text { including diabetes mellitus, hepatic insufficiency, } \\
\text { alcoholism, and hyperthyroidism; and past psychiatric } \\
\text { history. }\end{array}$ & $\begin{array}{l}\text { The incidence of isoniazid-associated } \\
\text { psychosis is rare }\end{array}$ & {$[131]$} \\
\hline Isoniazid & $\begin{array}{l}\text { A patient who developed a psychotic disorder after } 4 \\
\text { months of isoniazid prophylaxis for a positive } \\
\text { tuberculosis tine test. His symptoms resolved within } 2 \\
\text { weeks of discontinuing the isoniazid. }\end{array}$ & & {$[132]$} \\
\hline $\begin{array}{l}\text { Primary antituberculosis } \\
\text { (anti-TB) drugs }\end{array}$ & $\begin{array}{l}\text { Out of } 1149 \text { patients with established tuberculosis who } \\
\text { initially received anti-TB therapy neuropsychiatric } \\
\text { manifestations were observed during the initial phase } \\
\text { of therapy. }\end{array}$ & In $0.7 \%$ of $\mathrm{TB}$ patients & {$[133]$} \\
\hline
\end{tabular}


TABLE 5: Continued.

\begin{tabular}{|c|c|c|c|}
\hline Anti-TB drug & Reported adverse event & Frequency of event & References \\
\hline Ethionamide & $\begin{array}{l}\text { Adverse reactions like anxiety, depression, and } \\
\text { psychosis }\end{array}$ & $\begin{array}{l}\text { Has been reported in } 1 \%-2 \% \text { of patients } \\
\text { taking shorter courses of the drug, with } \\
\text { higher rates reported with prolonged } \\
\text { treatment }\end{array}$ & {$[134]$} \\
\hline Ethionamide & $\begin{array}{l}\text { A patient being treated with streptomycin, isoniazid, } \\
\text { pyrazinamide, ethionamide, and prednisolone } \\
\text { developed an acute psychotic reaction and died after } \\
\text { jumping from a second floor window. It is probable that } \\
\text { the reaction was precipitated by the ethionamide. }\end{array}$ & A case report & {$[135]$} \\
\hline Ethambutol & $\begin{array}{l}\text { Dizziness, disorientation, and auditory and visual } \\
\text { hallucinations developed after seven days of therapy. } \\
\text { Following discontinuation of anti-TB agents, the } \\
\text { psychiatric symptoms subsided. When the patient was } \\
\text { challenged with EMB, the same psychiatric symptoms } \\
\text { recurred, but resolved again after discontinuation of } \\
\text { EMB. EMB may be associated with mania, confusion, } \\
\text { and psychosis. }\end{array}$ & A case report & [136] \\
\hline Fluoroquinolones & $\begin{array}{l}\text { Have been implicated in rare occurrences of psychosis, } \\
\text { depression, suicidal ideation, delirium, and nightmares. } \\
\text { CNS toxicity occurs in } 1 \%-4.4 \% \text { of patients but with } \\
\text { serious adverse occurring in less than } 0.5 \% \text { of patients. }\end{array}$ & $\begin{array}{l}\text { A case of a woman who experienced an } \\
\text { acute psychosis secondary to } \\
\text { ciprofloxacin administration, which } \\
\text { resolved on cessation of therapy. } \\
\text { Two cases of organic psychosis, induced } \\
\text { by ofloxacin. } \\
8861 \text { patients receiving ciprofloxacin were } \\
\text { assessed worldwide, and } 138 \text { cases } \\
\text { presented with various neurological } \\
\text { adverse reactions. }\end{array}$ & $\begin{array}{l}{[137]} \\
{[138]} \\
{[139]} \\
{[140]}\end{array}$ \\
\hline
\end{tabular}

In a retrospective study conducted by the authors, 4189

reports of consultant psychiatric examinations were analyzed. In 29 patients, the suspicion of psychopathological ADR during treatment with ofloxacin or ciprofloxacin was documented.

Ofloxacin or ciprofloxacin Psychopathological findings included delirious states, paranoid, depressive and manic syndromes, agitation, sleep disturbances, and stupor. In elderly patients, delirious and paranoid syndromes were predominant, whereas affective disturbances occurred more often in younger patients.

Reported psychiatric disturbance in $0.7 \%$ of 4189 individuals treated with either ofloxacin or ciprofloxacin.

Severe psychiatric manifestations-including hallucinations, anxiety, depression, euphoria,

Cycloserine behavioral disorders, and suicidal ideation and/or attempts. Psychiatric symptoms appear most likely to present within the first 3 months of treatment.

Have been reported to occur in

HIV infection, and other factors. The above-mentioned risk factors are very prevalent in psychiatric populations and increase risk of progression from latent TB to active TB [104].

Patients suffering from pulmonary tuberculosis are reported to have psychiatric disorders like depression [212], anxiety, psychosis [83], and also many psychosocial problems $[37,213]$ like increased smoking [74], increased alcohol consumption [87], divorce, and isolation from the family [36]. However, it is important to draw the line between a psychosocial issue and a diagnosable mental disorder in order to address the effective interventions which necessitate different knowledge and skills [214].

Psychopathology may be a very important negative factor to treatment adherence [169] for patients with somatic disease, and nonadherence to treatment is a major setback for effective tuberculosis control in the community, possibly responsible for the appearance of drug-resistant $\mathrm{TB}$ which is caused by inconsistent or partial treatment of the disease [215] and probably responsible for nonadherence with latent TB therapy, which may increase risk of progression from 
TABLE 6: Clinically significant drug-drug interactions involving TB medications and psychiatric medications.

\begin{tabular}{|c|c|c|c|}
\hline TB medications & Psychiatric medications & Interactions & References \\
\hline Isoniazid, in therapeutic dose & & $\begin{array}{l}\text { Was found to inhibit markedly plasma, but not platelet, } \\
\text { MAO. }\end{array}$ & [149] \\
\hline \multirow{2}{*}{$\begin{array}{l}\text { Drug that inhibits monoamine } \\
\text { oxidase }\end{array}$} & \multirow[t]{2}{*}{ SSRIs or TCAs. } & $\begin{array}{l}\text { Is contraindicated because of the potential to induce } \\
\text { serotonin syndrome }\end{array}$ & {$[150]$} \\
\hline & & $\begin{array}{l}\text { No reports of serotonin syndrome induced by } \\
\text { combining SSRIs and isoniazid are published. }\end{array}$ & {$[151]$} \\
\hline Isoniazid & $\begin{array}{l}\text { Phenytoin and carbamazepine } \\
\text { selected benzodiazepines (valium } \\
\text { and others) } \\
\text { Valproate } \\
\text { Haldol. }\end{array}$ & $\begin{array}{l}\text { Isoniazid can cause increased phenytoin and } \\
\text { carbamazepine serum concentrations and toxicity. } \\
\text { Isoniazid inhibits metabolism of selected } \\
\text { benzodiazepines. } \\
\text { Inhibition of monoamine oxidase and histaminase by } \\
\text { Isoniazid can cause significant drug-food interactions. } \\
\text { isoniazid has a biphasic effect of inhibition-induction } \\
\text { on one cytochrome P450 isozyme, CYP2E1 and } \\
\text { increases hepatic and CNS valproate toxicity and haldol } \\
\text { toxicity. }\end{array}$ & $\begin{array}{l}{[152]} \\
{[153]}\end{array}$ \\
\hline Isoniazid & $\begin{array}{l}2 \text { patients who received isoniazid } \\
\text { in conjunction with } \\
\text { antidepressants. The first patient } \\
\text { was prescribed sertraline } \\
\text { ( } 150 \mathrm{mg} / \text { day) in combination } \\
\text { with isoniazid ( } 300 \mathrm{mg} / \text { day). The } \\
\text { second patient received } \\
\text { nefazodone ( } 400 \mathrm{mg} / \text { day) and } \\
\text { buspirone ( } 10 \mathrm{mg} / \text { day) in } \\
\text { conjunction with isoniazid } \\
(300 \mathrm{mg} / \text { day). }\end{array}$ & None of patients reported adverse effects. & {$[150]$} \\
\hline
\end{tabular}
(300 mg/day).

Isoniazid
Are metabolized by similar mechanisms.

Hepatic cytochrome P450 (CYP) enzymes are largely responsible for metabolism of isoniazid, citalopram, fluoxetine, fluvoxamine, paroxetine, and sertraline. While it has not been definitively established which isoenzymes are implicated in the metabolism of isoniazid, CYP2E1, CYP1A2, CYP2C9, CYP2C19, and CYP3A are inhibited to varying degrees by isoniazid. CYP2C19 and CYP3A were inhibited potently by isoniazid in a concentration-dependent manner. Both enzymes were inhibited approximately $40 \%$ by doses in the therapeutic range. Isoniazid induced competitive inhibition of CYP2D6 and weak noncompetitive inhibition of CYP2E1.

CYP2D6 is affected negligibly by isoniazid. The potential for drug interactions would appear to be minimal.

Paroxetine is metabolized
primarily by CYP2D6.

Citalopram appears to be metabolized primarily by CYP2C19 and/or CYP3A4.

Fluvoxamine is known to inhibit CYP1A2, CYP2C19, and possibly CYP3A3/4.

CYP2C19 and/or CYP3A4 are inhibited by isoniazid. It might not be the best choice for a patient taking isoniazid

CYP1A2, CYP2C19, and CYP3A3/4 are inhibited by isoniazid

Fluoxetine inhibits CYP2D6 and probably CYP2C9/10

significantly, and CYP3A3/4 and

Isoniazid
CYP3A3/4 is inhibited by isoniazid

$[161,162]$ increased potential for drug interactions.
[161-163] metabolite of fluoxetine, norfluoxetine inhibits CYP3A3/4 and has a half-life of 7 to 15 days. 
TABLE 6: Continued.

\begin{tabular}{lll}
\hline TB medications & Psychiatric medications & Interactions \\
\hline Isoniazid & $\begin{array}{l}\text { Sertraline probably inhibits } \\
\text { CYP3A. }\end{array}$ & CYP3A is implicated in the metabolism of isoniazid. \\
\hline Antidepressants, haldol, & $\begin{array}{l}\text { A62] } \\
\text { quetiapine, methadone, } \\
\text { phenytoin, valproic acid, } \\
\text { lamotrigine, buspirone, } \\
\text { benzodiazepines (diazepam, } \\
\text { tiazolam), and zolpidem. }\end{array}$ & Reduces their levels. \\
\hline Rifampin & Nortriptyline & $\begin{array}{l}\text { A case report } \\
\text { Higher than expected doses of nortriptyline were } \\
\text { required to obtain a therapeutic drug level while the } \\
\text { patient was receiving rifampin. }\end{array}$ \\
\hline
\end{tabular}

latent TB to active TB. Additionally, psychiatric disorders may hinder adaptation to chronic disease conditions, and it is known that adaptation is a crucial survival factor in chronic diseases [216].

Temporal and causative associations determine possible distinct categories of psychiatric conditions in TB patients (presented in Table 1).

\section{Results from Clinical Studies}

Research has shown that people infected with TB are more likely to develop mental and psychological problems than people not infected with the disease $[217,218]$. To be afflicted with pulmonary, tuberculosis is a unique and painful experience in the biopsychosocial history of an individual, and the emergent stress contributes to psychiatric morbidity [59].

Depression, posttraumatic stress disorder (PTSD), and acute stress disorder are the most common stress-related conditions of TB patients $[36,219]$. Reactions to the stressful situation brought about by the illness negatively affecting an individual's ability to work, in conjunction with social and respiratory isolation [220], lowered self-esteem, fear of spreading the illness to others, helplessness brought out by incapacitation due to chronic illness, and social stigma attached to this illness, are all plausible causes that one can postulate for depression and anxiety. Dependence on alcohol and other drugs could be the response to anxiety and depression [59].

The psychiatric morbidity of patients is considered to be a psychogenic reaction of neurotically predisposed people to their special situation and awareness that they are suffering from a severe and dangerous illness [221].

Prevalence studies (Table 2) reporting mean depression and anxiety rates of $46 \%-72 \%$ establish the need to address mental disorders in TB care [214].

Conversely, individuals with chronic mental illnesses present a series of risk factors that predispose them to extensive medical comorbidities $[102,222]$. Prevalence rates of tuberculosis among psychiatric patients are presented in Table 3, indicating that programs serving people with severe mental illness should regularly screen participants for $\mathrm{TB}$ infection and evaluate them for chemoprophylaxis in order to avoid the risk of developing active TB.

\section{Psychological Reactions and Disease Perceptions}

People believe that tuberculosis occurring in an individual is always an interruption in life, physically, psychologically, economically, and socially. Observations from the early days of the tuberculosis epidemic, before scientific studies, report that after the initial shock from the diagnosis, there is often a brief or prolonged period of denial, followed by resignation and depression, leading to distorted perceptions about the illness. Patients were described to exhibit strong emotions like fear, jealousy, vindictive behavior, anger, noncooperation, guilt, or a sense of shame. Rarely, suicides occurred, especially when the rest of the family tried to segregate the afflicted in a distant institution, or even stooped to a complete abandonment [223].

The scene changed dramatically in the fifties when tuberculosis became highly curable and preventable, assuming that physical, mental, economic, and social trauma had been rendered minimal, even that social stigma had nearly disappeared and needed no attention [109, 224].

Unfortunately, stigma is seen to play a huge role in the experience of illness by TB patients, and it is believed that most TB patients even after full recovery from the illness feel the disease can never be completely cured [225]. According to Lawn [226] "patient perception about TB is usually stained, and patients permanently hold negative feelings towards the disease." Disease-related stigma occurs when individuals with an illness are deemed undeserving of assistance and support from other individuals in the society (Schulte [227]). Over time, certain illnesses, such as TB, have been associated with reduced social status, and these negative reactions may impede coping and recovery [228]. The psychological adjustments to illness by a patient are negatively influenced primarily by the negative perceptions that other people within the society might hold (Fife and Wright [162]).

In other words, TB often has an impact on the physical, social and mental wellbeing of TB patients ( Rajeswari et al. [109]), and another element of this impact is the perception 
TABLE 7: Studies addressing factors affecting treatment adherence in TB patients.

\begin{tabular}{|c|c|c|}
\hline $\begin{array}{l}\text { First } \\
\text { author/ } \\
\text { references }\end{array}$ & Factors & Proposals \\
\hline $\begin{array}{l}\text { Pablos- } \\
\text { Méndez, } \\
1997[166] \\
\end{array}$ & $\begin{array}{l}\text { Of the } 184,48 \% \text { patients were nonadherent. In } \\
\text { multivariate analysis, only injection drug was used } \\
\text { and homelessness predicted nonadherence. }\end{array}$ & $\begin{array}{l}\text { These data lend support to directly observed therapy } \\
\text { in tuberculosis. }\end{array}$ \\
\hline $\begin{array}{l}\text { Oscherwitz, } \\
1997 \\
{[167]}\end{array}$ & $\begin{array}{l}46 \% \text { of persistently nonadherent patients were } \\
\text { homeless, } 81 \% \text { had drug or alcohol abuse, and } 28 \% \\
\text { had mental illness. }\end{array}$ & $\begin{array}{l}\text { Further improvements in the care of persistently } \\
\text { nonadherent patients may require more psychosocial } \\
\text { services, appropriate facilities for civil detention, and } \\
\text { detaining patients long enough to assure completion } \\
\text { of treatment. }\end{array}$ \\
\hline $\begin{array}{l}\text { Burman, } \\
1997 \\
{[168]}\end{array}$ & $\begin{array}{l}18 \% \text { who received outpatient DOT fulfilled one or } \\
\text { more criteria for noncompliance. Risk factors for } \\
\text { noncompliance were alcohol abuse and } \\
\text { homelessness. }\end{array}$ & $\begin{array}{l}\text { Innovative programs are needed to deal with } \\
\text { alcoholism and homelessness in patients with } \\
\text { tuberculosis. }\end{array}$ \\
\hline $\begin{array}{l}\text { Erhabor, } \\
2000 \\
{[169]}\end{array}$ & $\begin{array}{l}\text { The rate of compliance with antituberculosis } \\
\text { regimen under directly observed therapy was found } \\
\text { to be high ( } 73 \%) \text {. DOT improves the rate of } \\
\text { compliance. The only factor that significantly } \\
\text { influenced rate of compliance was proximity to the } \\
\text { chest clinic. Also, psychopathology could have } \\
\text { adversely affected the rate of compliance. }\end{array}$ & $\begin{array}{l}\text { Locating chest units in the existing primary health } \\
\text { care facilities will improve the rate of compliance } \\
\text { with antituberculosis therapy. More attention should } \\
\text { be paid to behavioral aspect of tuberculosis control. } \\
\text { Health workers involved in the management of these } \\
\text { patients should develop a higher index of suspicion } \\
\text { for possible psychopathology. }\end{array}$ \\
\hline $\begin{array}{l}\text { Manoharam } \\
(2001)[74]\end{array}$ & $\begin{array}{l}66.7 \% \text { of subjects completed their treatment. Only } \\
\text { smoking was found to be associated with poor } \\
\text { compliance in univariate analysis }\end{array}$ & $\begin{array}{l}\text { The habit of smoking, disregarding own health, and } \\
\text { not adhering to treatment instructions may be a } \\
\text { reflection of the subject's personality. }\end{array}$ \\
\hline $\begin{array}{l}\text { Felton, } 2005 \\
{[170]}\end{array}$ & $\begin{array}{l}\text { Factors associated with adherence to treatment: } \\
\text { patient related factors, provider characteristics, clinic } \\
\text { facilities, characteristics of treatment regimens, and } \\
\text { disease characteristics. }\end{array}$ & $\begin{array}{l}\text { Adherence to treatment for latent tuberculosis } \\
\text { infection: } \\
\text { a manual for healthcare providers }\end{array}$ \\
\hline $\begin{array}{l}\text { Lavigne, } \\
2006[171]\end{array}$ & $\begin{array}{l}\text { Smoking prevalence was } 21 \% .72 \% \text { of patients were } \\
\text { adherent to LTBI treatment }\end{array}$ & $\begin{array}{l}\text { Males and smokers need to have extra supervision to } \\
\text { ensure compliance with LTBI treatment. }\end{array}$ \\
\hline $\begin{array}{l}\text { Naidoo, } \\
2009[172]\end{array}$ & $\begin{array}{l}\text { Factors impacting adherence include: social and } \\
\text { economic recourses prior to the onset and during the } \\
\text { course of the disease, the causal attributions assigned } \\
\text { to TB, the social, cultural, economic, disease related, } \\
\text { and psychological challenges faced as a consequence } \\
\text { of having TB, quality of health care received, use of } \\
\text { traditional healing systems and feelings of } \\
\text { helplessness, depression, and lack of social support. }\end{array}$ & $\begin{array}{l}\text { Advocate a more holistic approach to health care } \\
\text { programs with the inclusion of mental health } \\
\text { services. }\end{array}$ \\
\hline $\begin{array}{l}\text { Munro, } \\
2007 \\
{[37]}\end{array}$ & $\begin{array}{l}\text { Structural factors: poverty, gender, and } \\
\text { discrimination. } \\
\text { Patient factors: motivation, knowledge, beliefs, and } \\
\text { attitudes and interpretations of illness and wellness. } \\
\text { Social context. } \\
\text { health care service factors. }\end{array}$ & $\begin{array}{l}\text { More patient-centred interventions, and far greater } \\
\text { attention to structural barriers, are needed to } \\
\text { improve treatment adherence and reduce the global } \\
\text { disease burden attributable to TB. }\end{array}$ \\
\hline $\begin{array}{l}\text { Gelmanova, } \\
2007[303]\end{array}$ & $\begin{array}{l}\text { Substance abuse was identified as the only factor that } \\
\text { was strongly associated with nonadherence. }\end{array}$ & $\begin{array}{l}\text { Few TB programmes that have explicitly offered } \\
\text { patients treatment for substance abuse generally have } \\
\text { demonstrated better outcomes than "unexpanded" } \\
\text { DOTS programmes. }\end{array}$ \\
\hline $\begin{array}{l}\text { K. Ito, } 2008 \\
{[163]}\end{array}$ & $\begin{array}{l}\text { Factors were classified into } 7 \text { categories; factors } \\
\text { related to disbelief and/or prejudice for diagnosis } \\
\text { and/or treatment (except factors related to drug } \\
\text { adverse effects) were observed in } 51.8 \% \text {, factors } \\
\text { related to economical problem in } 24.1 \% \text {, factors } \\
\text { related to job or studies in } 23.4 \% \text {, factors related to } \\
\text { drug adverse effects in } 22.6 \% \text {, factors related to } \\
\text { visiting out-patients departments in } 6.6 \% \text {, } \\
\text { psychiatric disease and/or drug abuse in } 4.4 \% \text {, others } \\
\text { in } 9.5 \% \text {. }\end{array}$ & $\begin{array}{l}\text { To improve the quality of tuberculosis medical care } \\
\text { and services including good and sufficient } \\
\text { explanations on TB and how to cure it and proper } \\
\text { managements for drug adverse effects and then to } \\
\text { expand public economical support for the costs of } \\
\text { medicine and travel expenses to medical facilities } \\
\text { and to make accessible time and place of the } \\
\text { tuberculosis outpatient clinic more convenient and } \\
\text { flexible for patients. }\end{array}$ \\
\hline
\end{tabular}


TABLE 7: Continued.

\begin{tabular}{ll}
\hline $\begin{array}{l}\text { First } \\
\text { author/ } \\
\text { references }\end{array}$ & Factors \\
\hline & \\
& \\
& $\begin{array}{l}\text { The factors contributing to noncompliance can be } \\
\text { grouped into three categories, namely, patient } \\
2008\end{array}$ \\
{$[173]$} & $\begin{array}{l}\text { related, health care, and community and treatment } \\
\text { factors. }\end{array}$
\end{tabular}

Proposals

Develop and implement patient-centred

interventions that encourage shared

decision-making regarding treatment. Provide ongoing (in-service) training to health staff to improve and upgrade their competencies with regard to health education and communication skills. Strengthen patient support and community advocacy programmes aimed at eradicating the stigma associated with the disease. Emphasise the particular needs of individual patients and tailor the role of support systems to their needs. Plan interventions to reduce the influence of poverty and gender on patients and their treatment adherence

\begin{tabular}{lll}
\hline $\begin{array}{l}\text { Husain, } \\
2008[88]\end{array}$ & $\begin{array}{l}\text { Depression and lack of perceived control over illness } \\
\text { in those suffering from tuberculosis are reported to } \\
\text { be independent predictors of poor adherence }\end{array}$ & $\begin{array}{l}\text { Treating psychological problems in patients with } \\
\text { tuberculosis may substantially improve treatment } \\
\text { adherence. }\end{array}$ \\
\hline $\begin{array}{l}\text { Kruk, 2008 } \\
{[174]}\end{array}$ & $\begin{array}{l}\text { The majority of defaulters across the studies } \\
\text { completed the 2-month intensive phase of treatment. }\end{array}$ & $\begin{array}{l}\text { New TB chemotherapeutic agents which can reduce } \\
\text { the length of treatment have the potential to improve } \\
\text { global TB treatment success rates. }\end{array}$ \\
\hline
\end{tabular}

Lack of knowledge about TB, nonsustainability of educational campaigns, side effects of drugs, hunger Matebesi, and lack of family support, stigma attached to TB, [175] and health-related factors such as the attitude of health care providers and the long delay in obtaining a diagnosis.

$16 \%$ of patients among patients receiving DOTS treatment were nonadherent to the anti-TB therapy. Bagchi, 2010 Smoking during treatment and travel-related cost factors were significantly associated with nonadherence in the newly diagnosed patients, while alcohol consumption and shortage of drugs were significant in the residual groups.

Factors related to the patient (lack of means, being a migrant worker, distance to treatment site, poor understanding of treatment, drug use, and mental illness), medical team (high patient load, low

Kizub, 2012 motivation, and lack of resources for tracking [177] defaulters), treatment organization (poor communication between treatment sites, no systematic strategy for patient education or tracking, and incomplete record keeping), and health care system and society.

Recommendations are made for the instigation of enhanced education programmes focusing on patients, the community, and health care providers.

[176]

Nine factors conceptually associated with medication adherence in TB patients: (1) communication with

Yin, 2012

[178] healthcare providers, (2) personal traits, (3)

confidence in curing TB, (4) social support, (5) mood disorders, (6) lifestyle and habits, (7) coping style, (8) access to healthcare, and (9) forgetfulness.
A 30-item TB medication adherence scale (TBMAS) with a positive predictive value of $65.5 \%$ and sensitivity of $82.9 \%$ was developed and incorporated the latest research in TB specific medication

Targeting easier access to drugs, an ensured drug supply, effective solutions for travel-related concerns, and modification of smoking and alcohol-related behaviors are essential for treatment adherence.

Interventions to enhance $\mathrm{TB}$ treatment completion should take into account the local context and multilevel factors that contribute to default. Qualitative studies involving health care workers directly involved in TB care can be powerful tools to identify contributing factors and define strategies to help reduce treatment default. adherence, where predictors for adherence such as patient behavior and patient-provider interaction in TB treatment have been explored. The resulting tool will help TB medical professionals identify not only TB patients with poor adherence but also potential reasons for nonadherence and help them to design and implement targeted interventions to improve adherence. 
of others in the community about $\mathrm{TB}$, which influences the self-perception of TB patients. The self-perception of a TB patient is influenced by the existing health-related beliefs in the community, the culture of the community, which a TB patient lives in, and the expected health behavior of a TB patient by the community.

Although patient's perceptions about TB remain largely unknown [72], yet the literature shows a lot of reactions of TB patients to the disclosure of their diagnosis and these reactions included feelings of loneliness, depression, suicidal thoughts, fear, apathy, shock, concern, surprise (in relation to the lack of symptoms), and acceptation [109, 115]. The possible reasons for these emotions may be the stigma discrimination and social isolation attached to the disease or "physical rehabilitation, illiteracy, lack of knowledge of $\mathrm{TB}$, or fear of loss of income on account of long duration of treatment." [109]

Studies reporting patients' psychological reactions and disease perceptions about TB are summarized in Table 4.

Evidence also suggests the correlation between susceptibility to tuberculosis and specific personality traits [229], and studies indicate that in a large number of tuberculosis cases emotional conflict appears to inhibit recovery, and major life changes [189] provoke relapses.

Emerging disciplines like psychoneuroimmunology and neuroendocrinology could pave the way to better understanding of the subject and explain how psychological distress may decrease proliferation of lymphocytes and natural killer cell function and provide clues to recovery from disease and prevent relapse [223].

\section{Psychiatric Disorders in Patients Receiving Antituberculosis Drugs}

Psychiatric complications have been associated with antituberculosis therapy since the 1950s $[116,117,122]$. The possible environmental and genetic factors of anti-TB medicationinduced adverse reactions have always been the matter of concern [230]. It is well documented that the risk of adverse reactions increases with age, malnutrition, and history of hepatitis [231, 232], human immunodeficiency virus infection, and hepatitis C virus infection [233]. Genetic factors like isoniazid-metabolizing enzyme gene polymorphisms [234] were studied a lot, but these studies also showed inconsistent results. Until now, the comprehensive study for environmental, genetic, clinical, and administrative factors has not been reported.

More specifically, adverse reactions concerning neuropsychiatric complications have been reported, mainly with isoniazid (INH) [134, 235, 236], which is a first line drug and with ethionamide (ETH) $[237,238]$ and cycloserine (CS) $[239,240]$ (both second-line drugs, reserved for patients with drug-resistant tuberculosis) [164, 241]. Psychiatric disorders in patients receiving TB medications are presented in Table 5.

\section{Discussion}

Nonadherence to therapy by patients has been cited as the principal obstacle in eliminating tuberculosis [242]. Studies indicate that up to half of all of patients with $\mathrm{TB}$ do not complete treatment [243], which contributes to prolonged infectiousness, drug resistance [244], relapse, and death [245]. WHO defines "treatment default" (nonadherence) as a treatment interrupted for two consecutive months, and it is well documented that $30 \%$ of all patients who are under selfadministered treatment do not adhere to the therapy in the first two or three months.

Different approaches for ensuring medication adherence have been adopted, since 1991, and include Directly Observed Therapy Short Course (DOTS) [246], medication monitors $[247,248]$, and legal action $[249,250]$, (the use of involuntary detention for persistently nonadherent patients as a last resort) resulting in cure rates of $>80 \%$ and default rates of $<10 \%$ [251]. A review of articles published from 1966 through 1996 on DOT programs for TB treatment found that treatment completion rates were greater than $90 \%$ when therapy was supervised [252, 253]. Having a health care worker present to directly observe patients taking each dose of anti-TB medication has been proposed as the best way to ensure adherence to treatment, thereby diminishing the risk of transmission, relapse or reactivation, and drug resistance [254].

However, even with this approach, patient nonadherence to DOT still occurs [255]. One problem cited is that it is difficult to anticipate who will comply with treatment [256]. Various factors such as age, gender [257], alcohol and drug dependence [166], absence of symptoms, adverse effects of drugs, absence of educational programs, quality of communication between patients and health workers [258260], health culture [261], beliefs [262, 263], incentives and transportation time [257], and poor economy [264] have been shown to be associated with nonadherence. In sum, social, cultural, and demographic factors [265] (including educational level and treatment literacy [266]), psychiatric illness, including substance abuse [267] (alcohol and drug) in addition to those related to medication and also to the process of health care delivery and most certainly previous history of nonadherence [166] have all been cited as the most important barriers to TB treatment adherence.

The ability to predict poor medication adherence at initiation of treatment and identify patients at greater risk of dropping out could help in dealing with the problem [268]. Recently, a 30-item TB medication adherence scale (TBMAS) with a positive predictive value of $65.5 \%$ and a sensitivity of $82.9 \%$ was developed and incorporated the latest research in TB specific medication adherence, where predictors for adherence such as patient behavior and patient-provider interaction in TB treatment have been explored. The resulting tool will help TB medical professionals identify not only TB patients with poor adherence but also potential reasons for nonadherence and help them to design and implement targeted interventions to improve adherence [178].

A study that focused on adherence to DOTS, carried out in India, verified the need to focus research on addressing the disease from the perspective of patients and health professionals, who are the essential elements in this process [269]. In the encounter between health professionals and patients, DOTS could be an opportunity for the manifestation of 
subjectivities and to help patients with tuberculosis to recover their capabilities for life during regular consultations. At the same time, it allows identifying vulnerabilities and needs that can be dealt with, during the process so as to overcome them [270], which points to the need for actions within a multidisciplinary team, according to the biopsychosocial model of health and illness, where adherence is conceived as a process, not of imposition, but rather of exchange and meeting, one that uses the understanding of the context of patients' lives as a trigger to meet social and health needs [271].

The presence of psychopathology has been found to be one of the causes of nonadherence with therapy in chest conditions $[32,33]$.

Not only psychiatric patients are at risk of getting TB infection, as they are often homeless or have unstable housing conditions and lack food and security, but they also frequently fail to comply with treatment for the same reasons [67].

Individuals who are dealing with issues of substance abuse, HIV infection, mental illness, intellectual disability, and are also often homeless/under-housed are at much higher risk of contracting latent $\mathrm{TB}$ infection and of developing active TB disease. This increased risk may be explained by the existence of a number of challenges that increase an individual's vulnerability to tuberculosis, such as inadequate access to food, shelter, and income; substandard and overcrowded shelter conditions; forced migration of shelter users; preexisting health conditions (e.g., hepatitis C, compromised immune system); structural and attitudinal barriers to effective health care; problems in the corrections system [272] (i.e., prison conditions); and immigration and refugee issues (e.g., lack of identification to access health care during first few months). These challenges also increase the probability that individuals living in these conditions will be unlikely to adhere with TB treatment.

In an earlier study [71] on a tuberculosis population, it was found that $30.2 \%$ of the population had diagnosable mental disorders and none of these were recognized by the clinic staff. Such lack of knowledge can contribute to negative, pessimistic or victim-blaming messages to $\mathrm{TB}$ patients $[273,274]$, which fuels patients' distrust and can lead to problematic treatment [161]. The importance of a nonjudgmental, nonblaming stance is often cited as foundational for psychotherapeutic care in TB [275] along with the adoption of more power sharing with TB patients. Specific strategies are also identified, including education to help recognize mental disorder, training in psychotherapeutic strategies [276], and communication skills building.

TB is a chronic illness, and research into chronic illnesses has indicated that psychological factors, particularly depression, and the patients' perceptions about their illness predict poor adherence. In order to maximize the rate of adherence, health workers involved in the management of these patients should develop a higher index of suspicion for possible psychopathology and utilize the available consultation/liaison psychiatric services [169].

Treating psychological problems in patients with tuberculosis may substantially improve treatment adherence.
According to studies, DOTS programmes are more likely to achieve better TB control outcomes if they include interventions aimed at improving diagnosis of alcohol and substance abuse and treating it concurrently with TB, [277, 278] and according to DOTS-Plus Guidelines, for MDR-TB patients, all healthcare workers treating drug-resistant TB should closely work with psychiatric services because there is a high baseline incidence of depression and anxiety in these patients, often connected with the chronicity and socioeconomic stress factors related to the disease [279].

According to all studies, irrespective of regional and population differences a common major factor implicating treatment adherence is the presence of psychopathology, especially depression, among tuberculous patients [280], and the high incidence of depression among these patients necessitates effective management [281] in order to improve treatment adherence and overall quality of life of these patients [282]. Results from these studies advocate a more holistic approach [91] to healthcare programs with the inclusion of mental health services in order to provide pretreatment psychiatric assessment and necessary intervention and eventually reduce default rate in tuberculosis control programs [34].

Awareness of adherence is, as a complex behavioral issue, influenced by many factors [283] and lack of a comprehensive and holistic understanding of barriers to and facilitators of, treatment adherence is currently a major obstacle to finding effective solutions [253, 284]. Knowledge about the degree that each of these factors correlates with psychopathology, and contributes to nonadherence is lacking, and prospective cohort studies addressing the cause-effect relationship between risk factors and psychopathology could clarify such issues.

Also, studies focused on human dimension [28] and on subjective experiences of health care consumers [285] may provide information on patient experiences of TB treatment adherence which may serve as a tool to better promote treatment and effectuate more patient-centered interventions [286].

Finally, randomized control trials investigating the effects of pharmacological and psychological interventions modified to address not only depression but also issues around adherence to treatment [287] and illness perceptions [288] need to be carried out.

Studies addressing factors affecting treatment adherence in pulmonary tuberculosis patients are presented in Table 7.

\section{Treatment of Comorbid Tuberculosis and Depression}

Mood disorders seem to be particularly common in TB patients compared with those with other medical diagnoses.

Currently, selective serotonin reuptake inhibitors (SSRIs) are recommended as the first-line treatment for depression and tend to be favored over other pharmacologic treatments such as tricyclic antidepressants (TCAs) and monoamine oxidase inhibitors (MAOIs) because of their relatively benign side effect profiles. 
However, in patients comorbid for TB, concerns have been raised over the potential for drug interactions between various SSRIs and isoniazid, based on the ability of isoniazid to inhibit monoamine oxidase in plasma [289]. Generally, the combination of SSRIs or TCAs with a drug that inhibits monoamine oxidase is contraindicated because of the potential to induce serotonin syndrome [149]. No reports of serotonin syndrome induced by combining SSRIs and isoniazid are published, and, currently, there is insufficient clinical evidence to definitively establish the potential for an adverse interaction between isoniazid and antidepressants $[151,153]$.

At the molecular level, there is evidence that isoniazid and SSRIs are metabolized by similar mechanisms [159]. Hepatic cytochrome P450 enzymes are largely responsible for metabolism of isoniazid, citalopram, fluoxetine, fluvoxamine, paroxetine, and sertraline. While it has not been definitively established which isoenzymes are implicated in the metabolism of isoniazid, CYP2E1, CYP1A2, CYP2C9, CYP2C19, and CYP3A are inhibited to varying degrees by isoniazid [154], and inhibition of these enzymes slows the elimination of coadministered drugs. All SSRIs appear to be metabolized by cytochrome P450 enzymes; however, the pharmacokinetic interactions of each drug are variable, and available evidence indicates that some SSRIs might be a better choice than others for concurrent treatment.

Clinically, significant drug-drug interactions involving TB medications, especially isoniazid and rifampin, and various psychiatric medications are presented in Table 6 .

\section{Conclusion}

Tuberculosis remains a leading infectious cause of mortality worldwide.

Studies report high rates of depression and anxiety among tuberculosis patients most likely related to social stigma, inadequate social support, and the physiologic impact of chronic disease. The paper integrates information about how these psychosocial factors complicate adherence to drug regimens and emphasizes the importance of attention to mental health needs to ensure positive treatment outcomes. depression was related to the duration of illness, and severity of the disease/excluded

\section{References}

[1] T. E. Herchline, B. A. Cunha, P. S. Chavis et al., Tuberculosis. Medscape Reference, WebMD, Updated: March, 2012.

[2] P. Martin, "Tuberculosis at the end of the century," MedDigest, vol. 22, pp. 10-11, 1996.

[3] P. M. Small, "Tuberculosis research: balancing the portfolio," Journal of the American Medical Association, vol. 276, no. 18, pp. 1512-1513, 1996.

[4] R. Rajeswari, R. Balasubramanian, M. Muniyandi, S. Geetharamani, X. Thresa, and P. Venkatesan, "Socio-economic impact of tuberculosis on patients and family in India," International Journal of Tuberculosis and Lung Disease, vol. 3, no. 10, pp. 869877, 1999.
[5] World Health Organization, Global Tuberculosis Control 2010, World Health Organization, Geneva, Switzerland, 2010, http:// www.who.int/tb/publications/global_report/en/index.html.

[6] C. Dye, S. Scheele, P. Dolin, V. Pathania, and M. C. Raviglione, "Global burden of tuberculosis: estimated incidence, prevalence, and mortality by country," Journal of the American Medical Association, vol. 282, no. 7, pp. 677-686, 1999.

[7] S. Waisbord, Behavioral Barriers in Tuberculosis Control: A Literature Review, The CHANGE Project/Academy for Educational Development, Washington, DC, USA, 2004.

[8] P. Brown, "A disease that is alive and kicking," World Health, vol. 46, no. 4, pp. 4-5, 1993.

[9] World Health Organisation, Fact Sheet 2007.

[10] Global Tuberculosis Control, WHO Report 1998 Global Tuberculosis Programme, World Health Organization, Geneva, Switzerland, 1998.

[11] J. M. Grange and A. Zumla, "Paradox of the global emergency of tuberculosis," The Lancet, vol. 353, no. 9157, p. 996, 1999.

[12] H. Saez, E. Valencia, S. Conover, and E. Susser, "Tuberculosis and HIV among mentally ill men in a New York City shelter," American Journal of Public Health, vol. 86, no. 9, pp. 1318-1319, 1996.

[13] T. R. Frieden, P. I. Fujiwara, R. M. Washko, and M. A. Hamburg, "Tuberculosis in New York City-turning the tide," The New England Journal of Medicine, vol. 333, no. 4, pp. 229-233, 1995.

[14] D. Alland, G. E. Kalkut, A. R. Moss et al., "Transmission of tuberculosis in New York City-an analysis by DNA fingerprinting and conventional epidemiologic methods," The New England Journal of Medicine, vol. 330, no. 24, pp. 1710-1716, 1994.

[15] E. Susser, R. Moore, and B. Link, "Risk factors for homelessness," Epidemiologic Reviews, vol. 15, no. 2, pp. 546-556, 1993.

[16] C. P. Theuer, P. C. Hopewell, D. Elias, G. F. Schecter, G. W. Rutherford, and R. E. Chaisson, "Human immunodeficiency virus infection in tuberculosis patients," Journal of Infectious Diseases, vol. 162, no. 1, pp. 8-12, 1990.

[17] L. N. Friedman, G. M. Sullivan, R. P. Bevilaqua, and R. Loscos, "Tuberculosis screening in alcoholics and drug addicts," American Review of Respiratory Disease, vol. 136, no. 5, pp. 1188$1192,1987$.

[18] M. T. McKenna, E. McCray, and I. Onorato, “The epidemiology of tuberculosis among foreign-born persons in the United States, 1986 to 1993," The New England Journal of Medicine, vol. 332, no. 16, pp. 1071-1076, 1995.

[19] A. G. Lopez, "Tuberculosis and the severely mentally ill," American Journal of Psychiatry, vol. 151, no. 1, pp. 151-152, 1994.

[20] H. L. McQuistion, P. Colson, R. Yankowitz, and E. Susser, "Tuberculosis infection among people with severe mental illness," Psychiatric Services, vol. 48, no. 6, pp. 833-835, 1997.

[21] M. S. Westaway and L. Wolmarans, "Depression and selfesteem: rapid screening for depression in black, low literacy, hospitalized tuberculosis patients," Social Science and Medicine, vol. 35, no. 10, pp. 1311-1315, 1992.

[22] H. S. Moffic and E. S. Paykel, "Depression in medical inpatients," British Journal of Psychiatry, vol. 126, no. 4, pp. 346353, 1975.

[23] S. V. Cavanaugh, "The prevalence of emotional and cognitive dysfunction in a general medical population: using the MMSE, GHQ, and BDI," General Hospital Psychiatry, vol. 5, no. 1, pp. $15-24,1983$.

[24] A. J. Trenton and G. W. Currier, "Treatment of comorbid tuberculosis and depression," Primary Care Companion to the Journal of Clinical Psychiatry, vol. 3, no. 6, pp. 236-243, 2001. 
[25] European Centre for Disease Prevention and Control (ECDC)/WHO Regional Office for Europe, Tuberculosis Surveillance in Europe 2008, ECDC, Stockholm, Sweden, 2010, http://www.ecdc.europa.eu/en/publications/Publications/1003 _SUR_tuberculosis_surveillance_in_europe_2008.pdf.

[26] A. Kochi, "The global tuberculosis situation and the new control strategy of the World Health Organization," Tubercle, vol. 72, no. 1, pp. 1-6, 1991.

[27] S. R. Benatar, "Prospects for global health: lessons from tuberculosis," Thorax, vol. 50, no. 5, pp. 487-489, 1995.

[28] J. M. Grange and F. Festenstein, "The human dimension of tuberculosis control," Tubercle and Lung Disease, vol. 74, no. 4, pp. 219-222, 1993.

[29] I. Smith, “Tuberculosis control learning games," Tropical Doctor, vol. 23, no. 3, pp. 101-103, 1993.

[30] S. P. Tripathy, "Multidrug-resistant tuberculosis," World Health, vol. 4, p. 19, 1993.

[31] E. Surmatojo, "When Tuberculosis treatment fails: a social behavioural account of patient adherence," American Review of Respiratory Disease, vol. 147, pp. 1311-1320, 1993.

[32] C. M. Bosley, Z. M. Corden, P. J. Rees, and G. M. Cochrane, "Psychological factors associated with use of home nebulized therapy for COPD," European Respiratory Journal, vol. 9, no. 11, pp. 2346-2350, 1996.

[33] J. Kolbe, "Asthma education, action plans, psychosocial issues and adherence," Canadian Respiratory Journal, vol. 6, no. 3, pp. 273-280, 1999.

[34] A. Bansal, S. Chaudhri, and S. Agnihotri, "Impact of psychiatric morbidity and personality trait on treatment completion and default in patients taking directly observed treatment for tuberculosis," European Respiratory Society, 2010.

[35] P. Kelly, "Isolation and stigma: the experience of patients with active tuberculosis," Journal of Community Health Nursing, vol. 16, no. 4, pp. 233-241, 1999.

[36] T. R. Ndoro, Attitudes and perceptions towards TB in Grahamstown East in a time of HIV/AIDSA [M.S. thesis of Commerce in Organizational Psychology], 2009.

[37] S. A. Munro, S. A. Lewin, H. J. Smith, M. E. Engel, A. Fretheim, and J. Volmink, "Patient adherence to tuberculosis treatment: a systematic review of qualitative research," PLoS Medicine, vol. 4, no. 7, pp. 1230-1245, 2007.

[38] P. Naidoo and K. Mwaba, "Helplessness, depression, and social support among people being treated for tuberculosis in South Africa," Social Behavior and Personality, vol.38, no. 10, pp. 13231334, 2010.

[39] U. Eram, I. A. Khan, Z. Tamanna, Z. Khan, N. Khaliq, and A. J. Abidi, "Patient perception of illness and initial reaction to the diagnosis of tuberculosis," Indian Journal of Community Medicine, vol. 31, no. 3, pp. 2006-07-2006-09, 2006.

[40] P. Vega, A. Sweetland, J. Acha et al., "Psychiatric issues in the management of patients with multidrug-resistant tuberculosis," International Journal of Tuberculosis and Lung Disease, vol. 8, no. 6, pp. 749-759, 2004.

[41] G. D. Natani, N. K. Jain, and T. N. Sharma, "Depression in tuberculosis patients: correlation with duration of disease and response to anti-tuberculous chemotherapy," Indian Journal of Tuberculosis, vol. 32, no. 4, pp. 195-198, 1985.

[42] S. L. Panchal, "Correlation with duration and depression in TB patients in rural Jaipur district," International Journal of Pharma and Bio Sciences, vol. 2, no. 2, p. B.263, 2011.
[43] M. Ota and M. Isshiki, "An outbreak of tuberculosis in a longterm care unit of a mental hospital," Kekkaku, vol. 79, no. 10, pp. 579-586, 2004.

[44] A. C. Moudgil and D. Pershad, "Psycho-social survey of tuberculosis patients of a sanatorium," Indian Journal of Tuberculosis, vol. 19, no. 1, pp. 34-38, 1972.

[45] S. Kuha, P. Moilanen, and R. Kampman, "The effect of social class on psychiatric psychological evaluations in patients with pulmonary tuberculosis," Acta Psychiatrica Scandinavica, vol. 51, no. 4, pp. 249-256, 1975.

[46] L. B. Dubey, "Psycho-social survey of T.B. Patients," Indian Journal of Tuberculosis, vol. 22, no. 2, p. 83, 1975.

[47] J. S. Sachdeva, C. S. Shergill, and B. S. Sidhu, "Prevalence of psychiatric morbidity among medical in-patients," Indian Journal of Psychiatry, vol. 28, no. 4, pp. 293-296, 1986.

[48] G. P. Maguire, D. L. Julier, and K. E. Hawton, "Psychiatric morbidity and referral on two general medical wards," British Medical Journal, vol. 1, no. 5902, pp. 268-270, 1974.

[49] D. R. Purohit, S. D. Purohit, and M. L. Dhariwal, "Incidence of depression in hospitalized T.B. patients," Indian Journal of Tuberculosis, vol. 25, no. 3, pp. 147-151, 1978.

[50] J. Kishore, V. P. Reddaiah, V. Kapoor, and J. S. Gill, "Characteristics of mental morbidity in a rural primary health centre of Haryana," Indian Journal of Psychiatry, vol. 38, no. 3, pp. 137$142,1996$.

[51] S. K. Nambi, J. Prasad, D. Singh, V. Abraham, A. Kuruvilla, and K. S. Jacob, "Explanatory models and common mental disorders among patients with unexplained somatic symptoms attending a primary care facility in Tamil Nadu," National Medical Journal of India, vol. 15, no. 6, pp. 331-335, 2002.

[52] G. Amin, S. Shah, and G. K. Vankar, "The prevalence and recognition of depression in primary care," Indian Journal of Psychiatry, vol. 40, pp. 364-369, 1998.

[53] M. Pothen, A. Kuruvilla, K. Philip, A. Joseph, and K. S. Jacob, "Common mental disorders among primary care attenders in vellore, South India: nature, prevalence and risk factors," International Journal of Social Psychiatry, vol. 49, no. 2, pp. 119125, 2003.

[54] B. S. Yadav, S. C. Jain, and G. Sharma, "Psychiatric morbidity in pulmonary tuberculosis," Indian Journal of Tuberculosis, vol. 27, no. 4, pp. 167-171, 1980.

[55] V. N. Bagadia, K. S. Ayyar, P. D. Lakdawala, S. M. Sheth, V. N. Acharya, and P. V. Pradhan, "Psychiatric morbidity among patients attending medical outpatient department," Indian Journal of Psychiatry, vol. 28, no. 2, pp. 139-144, 1986.

[56] S. Krishnamurthy, C. Shamasundar, O. M. Prakash, and N. Prabhakar, "Psychiatric morbidity in general practice: a preliminary report," Indian Journal of Psychiatry, vol. 23, no. 1, pp. 4043, 1981.

[57] S. K. Murthy, C. Shamasundar, O. Prakash, and N. Prabhakar, "Psychiatric morbidity in general practice-a preliminary report," Indian Journal of Psychiatry, vol. 23, no. 1, pp. 40-43, 1981.

[58] A. K. Tandon, S. K. Jain, R. K. Tandon, and R. Asare, "Psychosocial study of tuberculosjs patients," Indian Journal of Psychiatry, vol. 27, no. 4, pp. 171-173, 1980.

[59] P. J. Mathai, P. Ravindran, P. Joshi, and P. Sundaram, "Psychiatric morbidity in pulmonary tuberculosis-a clinical study," Indian Journal of Psychiatry, vol. 23, no. 1, pp. 66-68, 1981.

[60] L. N. Gupta, B. L. Bhatia, and R. C. Godara, "Life events, physical illness and psychiatric morbidity," Indian Journal of Psychiatry, vol. 23, no. 4, pp. 338-342, 1981. 
[61] M. L. Meghnani, P. D. Motiani, D. R. Purohit, R. D. Singh, and T. N. Sharma, "Depression in hospitalized patients of pulmonary tuberculosis and role of anti depressants-a pilot study," Lung India, vol. 6, no. 1, pp. 22-25, 1988.

[62] G. Singh, J. S. Sachdev, and H. Kaur, "Prevalence of depression among medical in-patients," Indian Journal of Psychiatry, vol. 21, no. 3, pp. 274-278, 1979.

[63] K. L. Immerman and L. E. Pankratova, "Characteristics of the nature and dynamics of neuropsychic disorders in patients with newly detected pulmonary tuberculosis undergoing intensive chemotherapy," Zhurnal Nevrologii i Psikhiatrii imeni S.S. Korsakova, vol. 88, no. 6, pp. 109-113, 1988.

[64] R. P. Singh et al., "Psychiatric morbidity in pulmonary tuberculosis," in Proceedings of the 1st Joint Conference on Tuberculosis and Chest Diseases, vol. 37, p. 102, 1989, Indian Journal of Tuberculosis.

[65] M. V. Vinogradov, I. I. Cherkashina, and M. I. Perel'man, "Mental state of patients with restricted forms of pulmonary tuberculosis," Problemy Tuberkuleza, no. 10, pp. 41-43, 1991.

[66] O. A. Abiodun, "A study of mental morbidity among primary care patients in Nigeria," Comprehensive Psychiatry, vol. 34, no. 1, pp. 10-13, 1993.

[67] M. T. Fullilove, R. Young, P. G. Panzer, and P. Muskin, "Psychosocial issues in the management of patients with tuberculosis," The Journal of Law, Medicine \& Ethics, vol. 21, no. 3-4, pp. 324-331, 1993.

[68] D. P. Goldberg and Y. Lecrubier, "Form and frequency of mental disorders across centres," in Mental Illness in General Health Care: An International Study, T. B. Üstün and N. Sartorius, Eds., pp. 323-334, John Wiley \& Sons, Chichester, UK, 1995.

[69] P. H. Silverstone, "Prevalence of psychiatric disorders in medical inpatients," Journal of Nervous and Mental Disease, vol. 184, no. 1, pp. 43-51, 1996.

[70] S. Chaudhri, S. K. Katiyar, R. P. Singh et al., "Drug default in pulmonary tuberculosis with special reference to psychiatric factors," Indian Journal of Tuberculosis, vol. 40, no. 3, p. 168, 1993.

[71] H. S. Aghanwa and G. E. Erhabor, "Demographic/socioeconomic factors in mental disorders associated with tuberculosis in southwest Nigeria," Journal of Psychosomatic Research, vol. 45, no. 4, pp. 353-360, 1998.

[72] M. S. Bhatia, S. K. Bhasin, and K. K. Dubey, "Psychosocial dysfunction in tuberculosis patients," Indian Journal of Medical Sciences, vol. 54, no. 5, pp. 171-173, 2000.

[73] I. O. Aydin and A. Uluşahin, "Depression, anxiety comorbidity, and disability in tuberculosis and chronic obstructive pulmonary disease patients: applicability of GHQ-12," General Hospital Psychiatry, vol. 23, no. 2, pp. 77-83, 2001.

[74] E. Manoharam, K. R. John, A. Joseph, and K. S. Jacob, "Psychiatric morbidity, patients' perspectives of illness and factors associated with poor medication compliance among the tuberculous in vellore, south India," Indian Journal of Tuberculosis, vol. 48, no. 2, pp. 77-80, 2001.

[75] S. K. Bhasin, A. Mittal, O. P. Aggarwa, and R. K. Chadha, "Illness behavior of tuberculosis patients undergoing dots therapy: a case-control study," Indian Journal of Tuberculosis, vol. 48, no. 2, pp. 81-86, 2001.

[76] J. J. Furin, C. D. Mitnick, S. S. Shin et al., "Occurrence of serious adverse effects in patients receiving community-based therapy for multidrug-resistant tuberculosis," International Journal of Tuberculosis and Lung Disease, vol. 5, no. 7, pp. 648-655, 2001.

[77] M. G. Rogacheva, "Social aspects in tuberculosis among mental patients," Problemy Tuberkuleza, no. 10, pp. 13-16, 2002.
[78] E. N. Lukashova, L. N. Igisheva, and I. F. Kopylova, "Psychological peculiarities in adolescent patients with tuberculosis," Probl Tuberk, no. 1, pp. 39-41, 2002.

[79] L. Yang, D. L. Wu, H. G. Guo, and J. W. Liu, "A study of the psychological and social factors in patients with pulmonary tuberculosis," Zhonghua Jie He He Hu Xi Za Zhi, vol. 26, no. 11, pp. 704-707, 2003.

[80] E. V. Sukhova, "Behavioral aggression in patients with pulmonary tuberculosis and a way of its correction," Problemy Tuberkuleza, no. 12, pp. 13-17, 2003.

[81] V. M. Sukhov and E. V. Sukhova, "Some specific features of life quality in patients with pulmonary tuberculosis," Problemy Tuberkuleza, no. 4, pp. 29-30, 2003.

[82] S. Aamir and Aisha, "Co-morbid anxiety and depression among pulmonary tuberculosis patients," Journal of the College of Physicians and Surgeons Pakistan, vol. 20, no. 10, pp. 703-704, 2010.

[83] T. R. Chandrashekar, P. Denzil, K. Rajendrkuma, A. R. Shantha, R. Hungund Bhagyashri, and V. Joshi Arun, "A study of psychiatric morbidity among patients suffering from pulmonary tuberculosis," Medico-Legal Update, vol. 12, no. 2, pp. 26-29, 2012.

[84] P. N. Aniebue, K. O. B. Okonkwo, and P. N. Aniebue, "Prevalence of depressive symptoms amongst pulmonary tuberculosis patients at the University of Nigeria Teaching Hospital, Enugu," Journal of College of Medicine, vol. 11, no. 2, pp. 120-124, 2006.

[85] I. Y. Gelmanova, S. Keshavjee, V. T. Golubchikova et al., "Barriers to successful tuberculosis treatment in Tomsk, Russian Federation: non-adherence, default and the acquisition of multidrug resistance," Bulletin of the World Health Organization, vol. 85, no. 9, pp. 649-732, 2007.

[86] G. Moussas, A. Tselebis, A. Karkanias et al., "A comparative study of anxiety and depression in patients with bronchial asthma, chronic obstructive pulmonary disease and tuberculosis in a general hospital of chest diseases," Annals of General Psychiatry, vol. 7, article 7, 2008.

[87] N. Chishinga, E. Kinyanda, H. A. Weiss, V. Patel, H. Ayles, and S. Seedat, "Validation of brief screening tools for depressive and alcohol use disorders among TB and HIV patients in primary care in Zambia," BMC Psychiatry, vol. 11, article 75, 2011.

[88] M. O. Husain, S. P. Dearman, I. B. Chaudhry, N. Rizvi, and W. Waheed, "The relationship between anxiety, depression and illness perception in tuberculosis patients in Pakistan," Clinical Practice and Epidemiology in Mental Health, vol. 4, article 4, 2008.

[89] M. K. Ntarangwi, Prevalence of depression among TB patients attending TB clinic at Mbagathi District hospital Nairobi, Kenya [M.Sc. Clinical Psychology Dissertation], 2008.

[90] B. A. Issa, A. D. Yussuf, and S. I. Kuranga, "Depression comorbidity among patients with tuberculosis in a university teaching hospital outpatient clinic in Nigeria," Mental Health in Family Medicine, vol. 6, no. 3, pp. 133-138, 2009.

[91] M. E. Kruijshaar, M. Lipman, M. L. Essink-Bot et al., "Health status of UK patients with active tuberculosis," International Journal of Tuberculosis and Lung Disease, vol. 14, no. 3, pp. 296302, 2010.

[92] A. Deribew, M. Tesfaye, Y. Hailmichael et al., "Common mental disorders in TB/HIV co-infected patients in Ethiopia," BMC Infectious Diseases, vol. 10, article 201, 2010.

[93] V. Patel, "Mental health in low- and middle-income countries," British Medical Bulletin, vol. 81-82, no. 1, pp. 81-96, 2007. 
[94] M. A. Sulehri, A. DogarI, H. Sohail et al., "Prevalence of depression among tuberculosis patients," Australian Primary Mathematics Classroom, vol. 4, no. 2, 2010.

[95] M. M. Adina, O. L. Necrelescu, and C. Bondor, "Depressive syndrome, anxiety and illness perception in Tuberculosis patients," in Recent Researches in Modern Medicine, 2011.

[96] C. Prakash and S. Sangita, "Study of Psychiatric co-morbidity in cases of tuberculosis patients undergoing treatment," Indian Journal of Public Health Research \& Development, vol. 2, no. 2, pp. 111-113, 2011.

[97] I. O. Mayowa and L. V. Olufolahan, "Prevalence of depression in tuberculosis patients in comparison with non-tuberculosis family contacts visiting the DOTS clinic in a Nigerian tertiary care hospital and its correlation with disease pattern," Mental Health in Family Medicine, vol. 8, no. 4, pp. 235-241, 2011.

[98] Tangyu Xiu Lu Jinqing Liangcai Song Lilian Juan, On the psychological problems of patients with pulmonary tuberculosis and Solutions, 2011.

[99] V. Williams and H. Kaur, "The psychosocial problems of pulmonary tuberculosis patients undergoing DOTS therapy (direct observed treatment short course therapy) in selected areas of jalandhar district, punjab," Journal of Pharmacy and Biological Sciences, vol. 1, no. 1, pp. 44-49, 2012.

[100] K. Peltzer, J. Louw, G. Mchunu, P. Naidoo, G. Matseke, and B. Tutshana, "Hazardous and harmful alcohol use and associated factors in tuberculosis public primary care patients in South Africa," International Journal of Environmental Research and Public Health, vol. 9, no. 9, pp. 3245-3257, 2012.

[101] K. Peltzer, P. Naidoo, G. Matseke, J. Louw, G. McHunu, and B. Tutshana, "Prevalence of post-traumatic stress symptoms and associated factors in tuberculosis (TB), TB retreatment and/or TB-HIV co-infected primary public health-care patients in three districts in South Africa," Psychology Health \& Medicine. In press.

[102] G. H. Collins, "Physique, mental illness and pulmonary tuberculosis," British Medical Journal, vol. 1, no. 4978, p. 1298, 1956.

[103] Y. Ohta, Y. Nakane, M. Mine et al., “The epidemiological study of physical morbidity in schizophrenics. 2. Association between schizophrenia and incidence of tuberculosis," Japanese Journal of Psychiatry and Neurology, vol. 42, no. 1, pp. 41-47, 1988.

[104] M. Sanchez, T. Nicholls, and G. Currier, "Risk factors for tuberculosis in the psychiatric emergency department," Emergency Psychiatry, vol. 4, pp. 33-34, 1998.

[105] N. Sánchez-Mora, O. Medina, B. Francisconi et al., "Risk factors for respiratory disease in chronic psychiatric in patients," European Journal of Psychiatry, vol. 21, no. 3, pp. 212-219, 2007.

[106] W. F. Pirl, J. A. Greer, C. Weissgarber, G. Liverant, and S. A. Safren, "Screening for infectious diseases among patients in a state psychiatric hospital," Psychiatric Services, vol. 56, no. 12, pp. 1614-1616, 2005.

[107] S. H. Hashemi, M. Mamani, S. Jamal-Omidi, A. Ghaleiha, and F. Keramat, "Screening for tuberculosis among patients with chronic psychiatric disorders in Hamedan," Iranian Journal of Clinical Infectious Diseases, vol. 4, no. 1, pp. 31-34, 2009.

[108] J. S. Cavanaugh, K. Powell, O. J. Renwick et al., "An outbreak of tuberculosis among adults with mental illness," The American Journal of Psychiatry, vol. 169, pp. 569-575, 2012.

[109] R. Rajeswari, M. Muniyandi, P. Balasubramanian, and P. R. Narayanan, "Perceptions of tuberculosis patients about their physical, mental and social well-being: a field report from south India," Social Science and Medicine, vol. 60, no. 8, pp. 1845-1853, 2005.
[110] K. Jaggarajamma, R. Ramachandran, N. Charles, V. Chandrasekaran, M. Muniyandi, and S. Ganapathy, "Psycho-social dysfunction: perceived and enacted stigma among tuberculosis patients registered under revised national tuberculosis control programme," The Indian Journal of Tuberculosis, vol. 55, no. 4, pp. 179-187, 2008.

[111] A. Courtwright and A. N. Turner, "Tuberculosis and stigmatization: pathways and interventions," Public Health Reports, vol. 125, supplement 4, pp. 34-42, 2010.

[112] M. E. Edginton, C. S. Sekatane, and S. J. Goldstein, "Patients' beliefs: do they affect tuberculosis control? A study in a rural district of South Africa," International Journal of Tuberculosis and Lung Disease, vol. 6, no. 12, pp. 1075-1082, 2002.

[113] N. Gibson, A. Cave, D. Doering, L. Ortiz, and P. Harms, "Socio-cultural factors influencing prevention and treatment of tuberculosis in immigrant and Aboriginal communities in Canada," Social Science and Medicine, vol. 61, no. 5, pp. 931-942, 2005.

[114] M. E. P. Seligman, Helplessness: On Depression, Development, and Death, W. H. Freeman, San Francisco, Calif, USA, 1975.

[115] C. A. Marra, F. Marra, V. C. Cox, A. Palepu, and J. M. Fitzgerald, "Factors influencing quality of life in patients with active tuberculosis," Health and Quality of Life Outcomes, vol. 2, article $58,2004$.

[116] W. S. Weidorn and F. Ervin, "Schizophrenic-like psychotic reaction with administration of isoniazid," Archives of Neurology and Psychiatry, vol. 72, p. 321, 1954.

[117] W. C. Lewis, G. Calden, J. R. Thurston, and W. E. Gilson, "Psychiatric and neurological reaction to cycloserine in the treatment of tuberculosis," Dis Chest, vol. 32, pp. 172-182, 1957.

[118] J. B. Silva Jr., “Tuberculose: guia de vigilância epidemiológica," The Jornal Brasileiro de Pneumologia, vol. 30, supplement 1, pp. S57-S86, 2004.

[119] M. A. Arbex, M. C. L. Varella, H. R. de Siqueira, and F. A. F. de Mello, "Antituberculosis drugs: drug interactions, adverse effects, and use in special situations. Part 1: first-line drugs," Jornal Brasileiro de Pneumologia, vol. 36, no. 5, pp. 626-640, 2010.

[120] C. E. Prasad, K. Krishnamurthy, and K. J. R. Murthy, "Psychiatric disorders in patients receiving anti-tuberculosis drugs," Indian Journal of Psychiatry, vol. 27, no. 4, pp. 311-314, 1985.

[121] P. K. Gupta, K. S. Sharma, N. K. Jain, B. B. Mathur, M. L. Gupta, and A. S. Rajpal, "INH-induced toxic psychosis. A report of eight cases," Indian Journal of Tuberculosis, vol. 28, no. 4, pp. 212-215, 1981.

[122] W. S. Weidorn and F. Erwin, "Schizophrenic-like psychotic reactions with adminitration of isoniazid," Archives of Neurology and Psychiatry, vol. 72, no. 3, pp. 321-324, 1954.

[123] R. Prasad, R. Garg, and S. K. Verma, "Isoniazid- and ethambutol-induced psychosis," Annals of Thoracic Medicine, vol. 3, no. 4, pp. 149-151, 2008.

[124] M. C. Agarwala, H. M. Kansal, and R. K. Gupta, "Toxic psychosis due to isoniazid," Indian Journal of Tuberculosis, vol. 22, no. 3, pp. 119-120, 1975.

[125] R. S. Bedi, "Isoniazid induced pyrexia and psychosis in a single individual," Indian Journal of Tuberculosis, vol. 41, pp. 269-270, 1994.

[126] V. K. Tiwari and S. M. Verma, "Homicide by a tuberculous prisoner possibly having drug induced acute delusional psychosis," Indian Journal of Tuberculosis, vol. 44, no. 2, pp. 95-96, 1997. 
[127] S. J. Martin and F. J. Bowden, "Ethambutol toxicity manifesting as acute onset psychosis," International Journal of STD and AIDS, vol. 18, no. 4, pp. 287-288, 2007.

[128] C. W. Hsu, K. A. Chu, T. Lu, R. S. Lai, and J. Y. Lu, "Ethambutolinduced psychosis: a case report," Zhonghua Yi Xue Za Zhi, vol. 62, pp. 724-727, 1999.

[129] M. R. Holdiness, "Neurological manifestations and toxicities of the antituberculosis drugs. A review," Medical Toxicology and Adverse Drug Experience, vol. 2, no. 1, pp. 33-51, 1987.

[130] C. Bonilla, P. G. Portocarrero, P. G. Suárez et al., "Reacciones adversas a fármacos antituberculosos (RAFA) en tratamientos directamente observados (DOTS), Peru 1991-1999," in Tuberculosis en el Perú: Informe, pp. 99-106, Ministerio de Salud del Perú, Lima, Peru, 2000.

[131] K. A. Pallone, M. P. Goldman, and M. A. Fuller, "Isoniazidassociated psychoses: case report and review of the literature," The Annals of Pharmacotherapy, vol. 27, pp. 167-169, 1993.

[132] J. A. Bourgeois, M. Zelenko, and B. S. Waraich, "Psychotic disorder associated with isoniazid," Military Medicine, vol. 161, no. 11, p. 707, 1996.

[133] B. E. Gülbay, Ö. U. Gürkan, Ö. A. Yıldız et al., "Side effects due to primary antituberculosis drugs during the initial phase of therapy in 1149 hospitalized patients for tuberculosis," Respiratory Medicine, vol. 100, no. 10, pp. 1834-1842, 2006.

[134] Z. Y. Ibrahim and J. J. Menke, "Comment: isoniazid-induced psychosis," The Annals of Pharmacotherapy, vol. 28, no. 11, p. 1311, 1994.

[135] R. K. Narang, "Acute psychotic reaction probably caused by ethionamide," Tubercle, vol. 53, no. 2, pp. 137-138, 1972.

[136] R. W. Pickles and D. W. Spelman, "Suspected ethambutolinduced mania," Medical Journal of Australia, vol. 164, pp. 445446, 1996.

[137] J. P. Mulhall and L. S. Bergmann, "Ciprofloxacin-induced acute psychosis," Urology, vol. 46, no. 1, pp. 102-103, 1995.

[138] M. Zaudig, M. von Bose, M. M. Weber, D. Bremer, and W. Zieglgansberger, "Psychotoxic effects of ofloxacin," Pharmacopsychiatry, vol. 22, no. 1, pp. 11-15, 1989.

[139] P. Schacht, G. Arcieri, J. Branolte et al., "Worldwide clinical data on efficacy and safety of ciprofloxacin," Infection, vol. 16, supplement 1, pp. S29-S43, 1988.

[140] E. A. LaSalvia, G. J. Domek, and D. F. Gitlin, "Fluoroquinoloneinduced suicidal ideation," General Hospital Psychiatry, vol. 32, no. 1, pp. 108-110, 2010.

[141] M. Hollweg, H. P. Kapfhammer, M. Krupinski, and H. J. Möller, "Psychopathologic syndromes during treatment with gyrase inhibitors," Nervenarzt, vol. 68, no. 1, pp. 38-47, 1997.

[142] N. Riska, "Tolerance to cycloserine," Scandinavian Journal of Respiratory Diseases, vol. 71, pp. 209-216, 1970.

[143] C. Stephanopoulos and H. Zoumbouloglou, "Clinical tolerance to cycloserine," Scandinavian Journal of Respiratory Diseases, vol. 71, pp. 235-238, 1970.

[144] E. Dissmann, “Experience with cycloserine," Scandinavian Journal of Respiratory Diseases, vol. 71, pp. 239-243, 1970.

[145] N. Bethlem, "Results of treatment of pulmonary tuberculosis with cycloserine in association with other drugs," Scandinavian Journal of Respiratory Diseases, vol. 71, pp. 244-249, 1970.

[146] B. Helmy, "Side effects of cycloserine," Scandinavian Journal of Respiratory Diseases, vol. 71, pp. 220-225, 1970.

[147] M. Pasargiklian and L. Biondi, "Neurologic and behavioral reactions of tuberculosis patients treated with cycloserine,"
Scandinavian Journal of Respiratory Diseases, vol. 71, pp. 201208, 1970.

[148] J. M. Leston, J. C. Rey, L. J. Gonzalez Montaner, A. Grondona, and P. N. Zavalla, "Psychosomatic reactions to cycloserine in the treatment of tuberculosis," Scandinavian Journal of Respiratory Diseases, vol. 71, pp. 231-234, 1970.

[149] M. E. Evans and K. J. Kortas, "Potential interaction between isoniazid and selective serotonin-reuptake inhibitors," American Journal of Health-System Pharmacy, vol. 52, no. 19, pp. 21352136, 1995.

[150] P. Malek-Ahmadi, M. Chavez, and S. A. Contreras, "Coadministration of isoniazid and antidepressant drugs," Journal of Clinical Psychiatry, vol. 57, no. 11, p. 550, 1996.

[151] I. H. Stockley, "Lack of clinical evidence for potential interaction between isoniazid and selective serotonin-reuptake inhibitors," American Journal of Health-System Pharmacy, vol. 53, no. 18, p. 2217, 1996.

[152] T. H. Self, C. R. Chrisman, A. M. Baciewicz, and M. S. Bronze, "Isoniazid drug and food interactions," American Journal of the Medical Sciences, vol. 317, no. 5, pp. 304-311, 1999.

[153] C. K. Smith and D. T. Durack, "Isoniazid and reaction to cheese," Annals of Internal Medicine, vol. 88, pp. 520-521, 1978.

[154] Z. Desta, N. V. Soukhova, and D. A. Flockhart, "Inhibition of cytochrome P450 (CYP450) isoforms by isoniazid: potent inhibition of CYP2C19 and CYP3A," Antimicrobial Agents and Chemotherapy, vol. 45, no. 2, pp. 382-392, 2001.

[155] S. H. Sindrup, K. Brosen, M. G. J. Hansen, T. Aaes-Jorgensen, K. F. Overo, and L. F. Gram, "Pharmacokinetics of citalopram in relation to the sparteine and the mephenytoin oxidation polymorphisms," Therapeutic Drug Monitoring, vol. 15, no. 1, pp. 11-17, 1993.

[156] K. Kobayashi, K. Chiba, T. Yagi et al., "Identification of cytochrome $\mathrm{P} 450$ isoforms involved in citalopram $\mathrm{N}$ desmethylation by human liver microsomes," Journal of Pharmacology and Experimental Therapeutics, vol. 280, pp. 927-933, 1997.

[157] L. F. Gram, M. G. J. Hansen, S. H. Sindrup et al., "Citalopram: interaction studies with levopromazine, imipramine, and lithium," Therapeutic Drug Monitoring, vol. 15, pp. 18-24, 1993.

[158] S. H. Preskorn, "Clinically relevant pharmacology of selective serotonin reuptake inhibitors: an overview with emphasis on pharmacokinetics and effects on oxidative drug metabolism," Clinical Pharmacokinetics, vol. 32, supplement 1, pp. 1-21, 1997.

[159] S. Caccia, "Metabolism of the newer antidepressants: an overview of the pharmacological and pharmacokinetic implications," Clinical Pharmacokinetics, vol. 34, no. 4, pp. 281-302, 1998.

[160] C. Hiemke and S. Härtter, "Pharmacokinetics of selective serotonin reuptake inhibitors," Pharmacology and Therapeutics, vol. 85, no. 1, pp. 11-28, 2000.

[161] J. E. Oeltmann, J. S. Kammerer, E. S. Pevzner, and P. K. Moonan, "Tuberculosis and substance abuse in the United States, 19972006," Archives of Internal Medicine, vol. 169, no. 2, pp. 189-197, 2009.

[162] B. L. Fife and E. R. Wright, "Managing HIV stigma," Social Science and Medicine, vol. 54, pp. 1093-1110, 2000.

[163] I. T. O. Kunihiko, T. Yoshiyama, Y. Nagata, N. Kobayashi, S. Kato, and N. Ishikawa, "What is needed to prevent defaulting from tuberculosis treatment?" Kekkaku, vol. 83, no. 9, pp. 621$628,2008$. 
[164] H. M. Blumberg, W. J. Burman, R. E. Chaisson et al., "American Thoracic Society/Centers for Disease Control and Prevention/Infectious Diseases Society of America: treatment of tuberculosis," American Journal of Respiratory and Critical Care Medicine, vol. 167, no. 4, pp. 603-662, 2003.

[165] J. M. Bebchuk and D. E. Stewart, "Drug interaction between rifampin and nortriptyline: a case report," International Journal of Psychiatry in Medicine, vol. 21, no. 2, pp. 183-187, 1991.

[166] A. Pablos-Méndez, C. A. Knirsch, R. G. Barr, B. H. Lerner, and T. R. Frieden, "Nonadherence in tuberculosis treatment: predictors and consequences in New York City," American Journal of Medicine, vol. 102, no. 2, pp. 164-170, 1997.

[167] T. Oscherwitz, J. P. Tulsky, S. Roger et al., "Detention of persistently nonadherent patients with tuberculosis," Journal of the American Medical Association, vol. 278, no. 10, pp. 843-846, 1997.

[168] W. J. Burman, D. L. Cohn, C. A. Rietmeijer, F. N. Judson, J. A. Sbarbaro, and R. R. Reves, "Noncompliance with directly observed therapy for tuberculosis: epidemiology and effect on the outcome of treatment," Chest, vol. 111, no. 5, pp. 1168-1173, 1997.

[169] G. E. Erhabor, H. S. Aghanwa, M. Yusuph, R. A. Adebayo, F. A. Arogundade, and A. Omidiora, "Factors influencing compliance in patients with tuberculosis on directly observed therapy at Ile-Ife, Nigeria," East African Medical Journal, vol. 77, no. 5, pp. 235-239, 2000.

[170] C. P. Felton, Adherence to Treatment for Latent Tuberculosis Infection: A Manual For Health Care Providers, National Tuberculosis Center, 2005.

[171] M. Lavigne, I. Rocher, C. Steensma, and P. Brassard, "The impact of smoking on adherence to treatment for latent tuberculosis infection," BMC Public Health, vol. 6, article 66, 2006.

[172] P. Naidoo, J. Dick, and D. Cooper, "Exploring tuberculosis patients' adherence to treatment regimens and prevention programs at a public health site," Qualitative Health Research, vol. 19, no. 1, pp. 55-70, 2009.

[173] G. Norgbe, "Factors responsible for the high default rate of tuberculosis patients participating in direct observed treatment short course," 2008.

[174] M. E. Kruk, N. R. Schwalbe, and C. A. Aguiar, "Timing of default from tuberculosis treatment: a systematic review," Tropical Medicine and International Health, vol. 13, no. 5, pp. 703-712, 2008.

[175] Z. Matebesi and C. Timmerman, "The TB patient: qualitative evidence of perceived factors affecting treatment compliance," Joint research project on tuberculosis control in the Free State, South Africa: From infection to cure.

[176] S. Bagchi, G. Ambe, and N. Sathiakumar, "Determinants of poor adherence to anti-tuberculosis treatment in Mumbai, India," International Journal of Preventive Medicine, vol. 1, no. 4, pp. 223-232, 2010.

[177] D. Kizub, I. Ghali, R. Sabouni et al., "Qualitative study of perceived causes of tuberculosis treatment default among health care workers in Morocco," The International Journal of Tuberculosis and Lung Disease, vol. 16, no. 9, pp. 1214-1220, 2012.

[178] X. Yin, X. Tu, Y. Tong et al., "Development and validation of a tuberculosis medication adherence scale," PLoS One, vol. 7, no. $12,2012$.

[179] A. B. Bloch, "Screening for tuberculosis and tuberculosis infection in high-risk populations. Recommendations of the advisory council for the elimination of tuberculosis," Morbidity and Mortality Weekly Report, vol. 44, no. 11, pp. 18-34, 1995.
[180] K. Eisenstaedt, "Phthisis through the eyes of history," Indian Medical Record, vol. 64, p. 138, 1944.

[181] L. F. Flick, Development of Our Knowledge of Tuberculosis, Wickersham Printing, Philadelphia, Pa, USA, 1925.

[182] B. R. Merrill, "Some psychosomatic aspects of pulmonary tuberculosis. A review of the English language literature," Journal of Nervous \& Mental Disease, vol. 117, no. 1, pp. 9-28, 1953.

[183] T. S. Clouston, "Tuberculosis and insanity," The British Journal of Psychiatry, vol. 9, pp. 36-65, 1863.

[184] J. Katz, R. E. Plunkett, and M. E. Thompson, "Prevalence of pulmonary tuberculosis in New York State institutions for the mentally ill," The Psychiatric Quarterly, vol. 19, no. 4, pp. 644656, 1945.

[185] J. K. Deegan, J. E. Culp, and F. Beck, "Epidemiology of tuberculosis in a mental hospital," American Journal of Public Health, vol. 32, no. 4, pp. 345-351, 1942.

[186] A. M. Muhl, "Fundamental personality trends in tuberculous women," Psychoanalytical, vol. 10, pp. 380-430, 1923.

[187] E. A. Strecker, F. J. Braceland, and B. Gordon, "Mental attitudes of tuberculous patients," Merit Hygiene, vol. 22, p. 529, 1938.

[188] K. Brodman, B. Mittelmann, D. Wechsler, A. Weider, H. G. Wolff, and M. D. Meixner, "The incidence of personality disturbances and their relation to age, rank and duration of hospitalization in patients with medical and surgical disorders in a military hospital," Psychosomatic Medicine, vol. 9, pp. 45-49, 1947.

[189] B. Berle, "Emotional factors and tuberculosis. A critical review of the literature," Psychosomatic Medicine, vol. 10, no. 6, pp. 366373, 1948.

[190] G. Day, "Observations on the psychology of the tuberculous," The Lancet, vol. 248, no. 6429, pp. 703-706, 1946.

[191] M. J. Breuer, "The psychic element in the etiology of tuberculosis," The American Review of Tuberculosis, vol. 31, p. 233, 1935.

[192] A. M. Forster and C. E. Shepard, "Abnormal mental states in tuberculosis," The American Review of Tuberculosis, vol. 25, p. 324, 1932.

[193] I. D. Bobrowitz, "Why they leave against advice," Modern Hospital, vol. 67, p. 65, 1946, Bulletin of the National Tuberculosis Association, vol. 32, p. 151, 1946.

[194] B. L. Ashmore and F. G. Bell, "Neuropsychiatric concomitants of tuberculosis," Medical Bulletin. United States. Veterans Administration, vol. 20, p. 190, 1943-1944.

[195] S. E. Jelliffe and E. Evans, "Psychotherapy and tuberculosis," The American Review of Tuberculosis, vol. 3, p. 417, 1919.

[196] E. Wittkower and G. S. Todd, "The psychological aspects of sanatorium management," The Lancet, vol. 251, no. 6489, pp. 4953, 1948.

[197] J. Hartz, "Tuberculosis and personality conflicts," Psychosomatic Medicine, vol. 6, pp. 17-22, 1944.

[198] K. Fantl, "Psychiatry and tuberculosis," California Medicine, vol. 73, no. 6, pp. 538-540, 1950.

[199] M. de Hert, C. U. Correll, J. Bobes et al., "Physical illness in patients with severe mental disorders. I. Prevalence, impact of medications and disparities in health care," World Psychiatry, vol. 10, no. 1, pp. 52-77, 2011.

[200] N. Sartorius, "Physical illness in people with mental disorders," World Psychiatry, vol. 6, no. 1, pp. 3-4, 2007.

[201] F. Alexander, T. M. French, and G. E. Pollock, Psychosomatic Specificity Vol. 1. Experimental Studies and Results, University of Chicago Press, Chicago, Ill, USA, 1968. 
[202] P. M. Shyangwa, D. Joshi, S. Sherchan, and K. B. Thapa, "Psychiatric morbidity among physically ill persons in eastern Nepal," Nepal Medical College Journal, vol. 11, no. 2, pp. 118-122, 2009.

[203] WHO, "Mental health, new understanding, new hope," The World Health Report, WHO, Geneva, Switzerland, 2001, http://www.who.int/whr/2001/en/.

[204] M. Prince, V. Patel, S. Saxena et al., "No health without mental health," The Lancet, vol. 370, no. 9590, pp. 859-877, 2007.

[205] E. H. Cassem, "Depression and anxiety secondary to medical illness," Psychiatric Clinics of North America, vol. 13, no. 4, pp. 597-612, 1990.

[206] N. H. Cassem and J. G. Bernstein, "Depressed patients," in Massachusetts General Hospital Handbook of General Hospital Psychiatry, T. A. Stern, G. L. Fricchione, W. H. Cassen, M. S. Jellinek, and J. F. Rosenbanm, Eds., pp. 25-68, Mosby; Elsevier, Philadelphia, Pa, USA, 5th edition, 2004.

[207] E. Lykouras, H. Ioannidis, and A. Voulgaris, "Depression in general hospital patients: preliminary results," Archives of Hellenic Medicine, vol. 4, pp. 287-289, 1987.

[208] S. Giannitsi and A. Liakos, "Preliminary observations after implementation of two years of liaison psychiatry service in a general hospital," Encephalopathy, vol. 22, p. 138, 1985.

[209] L. C. Campbell, D. J. Clauw, and F. J. Keefe, "Persistent pain and depression: a biopsychosocial perspective," Biological Psychiatry, vol. 54, no. 3, pp. 399-409, 2003.

[210] M. E. Kunik, K. Roundy, C. Veazey et al., "Surprisingly high prevalence of anxiety and depression in chronic breathing disorders," Chest, vol. 127, no. 4, pp. 1205-1211, 2005.

[211] K. Slama, C. Y. Chiang, D. A. Enarson et al., "Tobacco and tuberculosis: a qualitative systematic review and meta-analysis," International Journal of Tuberculosis and Lung Disease, vol. 11, no. 10, pp. 1049-1061, 2007.

[212] J. Berg, A. Nyamathi, A. Christiani, D. Morisky, and B. Leake, "Predictors of screening results for depressive symptoms among homeless adults in Los Angeles with latent tuberculosis," Research in Nursing and Health, vol. 28, no. 3, pp. 220-229, 2005.

[213] T. H. Holmes, N. G. Hawkins, C. E. Bowerman, E. R. Clarke, and J. R. Joffe, "Psychosocial and psychophysiologic studies of tuberculosis," Psychosomatic Medicine, vol. 19, no. 2, pp. 134-143, 1957.

[214] I. H. AmyBender, I. Hyman, and S. Guruge, "Exploring tuberculosis, mental health, and immigrant health through a syndemic approach," CERIS Final Report, 2011.

[215] A. Jain and P. Dixit, "Multidrug resistant to extensively drug resistant tuberculosis: what is next?" Journal of Biosciences, vol. 33, no. 4, pp. 605-616, 2008.

[216] M. Vanderpool, "Resilience: a missing link in our understanding of survival," Harvard Review of Psychiatry, vol. 10, pp. 302306, 2002.

[217] I. O. Aydin and A. Uluşahin, "Depression, anxiety comorbidity, and disability in TB and chronic obstructive pulmonary disease patients: applicability of GHQ-12," General Hospital Psychiatry, vol. 23, pp. 77-83, 2001.

[218] L. P. Varma, "Depression in pulmonary tuberculosis," Journal of Clinical Psychology, vol. 2, p. 49, 1974.

[219] C. de la Rey, N. Duncan, and L. Swartz, Psychology Introduction, Oxford University, Cape Town, South Africa, 2006.

[220] L. Kelly-Rossini, "The experience of respiratory isolation for HIV-infected persons with tuberculosis," Journal of the Association of Nurses in AIDS Care, vol. 7, no. 1, pp. 29-36, 1996.
[221] E. Slater and M. Roth, Clinical Psychiatry, Bailliere Tindall \& Cassell, London, UK, 3rd edition, 1974.

[222] D. V. Jeste, J. A. Gladsjo, L. A. Lindamer, and J. P. Lacro, "Medical comorbidity in schizophrenia," Schizophrenia Bulletin, vol. 22, no. 3, pp. 413-430, 1996.

[223] L. Kant and D. R. Nagpaul, "Psychiatric disorders and illness perceptions in tuberculosis," The Indian Journal of Tuberculosis, vol. 48 , no. 2, pp. 55-56, 2001.

[224] S. Morankar and D. Desmuckh, Social Stigma and Tuberculosis: Societal Response, Centre for Research and Development (CHRD) Maharastra Association of Anthropological Sciences (MAAS), Maharastra, India, 2001.

[225] N. H. Long, E. Johansson, V. K. Diwan, and A. Winkvist, "Fear and social isolation as consequences of tuberculosis in Vietnam: a gender analysis," Health Policy, vol. 58, no. 1, pp. 69-81, 2001.

[226] S. D. Lawn, “Tuberculosis in Ghana: social stigma and compliance with treatment," International Journal of Tuberculosis and Lung Disease, vol. 4, no. 12, pp. 1190-1191, 2000.

[227] J. M. Schulte, "Latent tuberculosis in children," International Journal of Tuberculosis and Lung Disease, vol. 84, pp. 196-201, 2002.

[228] R. L. Rosenfield, "Infectious disease in clinical practice," Social Science and Medicine, vol. 41, pp. 678-698, 1997.

[229] "Psychological Effects of Tuberculosis," Disease Ecology, 2011, http://www.ncbi.nlm.nih.gov/pmc/articles/PMC1520764/pdf/ califmed.

[230] Y. Y. Xia, D. Y. Hu, F. Y. Liu et al., "Design of the anti-tuberculosis drugs induced adverse reactions in China national tuberculosis prevention and control scheme study (ADACS)," BMC Public Health, vol. 10, article 267, 2010.

[231] R. Shakya, B. S. Rao, and B. Shrestha, "Incidence of hepatotoxicity due to antitubercular medicines and assessment of risk factors," Annals of Pharmacotherapy, vol. 38, no. 6, pp. 10741079, 2004.

[232] A. Fernández-Villar, B. Sopeña, J. Fernández-Villar et al., “The influence of risk factors on the severity of anti-tuberculosis drug-induced hepatotoxicity," International Journal of Tuberculosis and Lung Disease, vol. 8, no. 12, pp. 1499-1505, 2004.

[233] J. R. Ungo, D. Jones, D. Ashkin et al., "Antituberculosis druginducted hepatotoxicity: the role of hepatitis $\mathrm{C}$ virus and the human immunodeficiency virus," American Journal of Respiratory and Critical Care Medicine, vol. 15, no. 7, pp. 1871-1876, 1998.

[234] F. Sun, Y. Chen, Y. Xiang, and S. Zhan, "Drug-metabolising enzyme polymorphisms and predisposition to anti-tuberculosis drug-induced liver injury: a meta-analysis," International Journal of Tuberculosis and Lung Disease, vol. 12, no. 9, pp. 994-1002, 2008.

[235] W. Gnam, A. Flint, and D. Goldbloom, "Isoniazid-induced hallucinosis: response to pyridoxine," Psychosomatics, vol. 34, no. 6, pp. 537-539, 1993.

[236] A. O. Alao and J. C. Yolles, "Isoniazid-induced psychosis," Annals of Pharmacotherapy, vol. 32, no. 9, pp. 889-891, 1998.

[237] J. Simeon, M. Fink, T. M. Itil, and D. Ponce, " $d$-Cycloserine therapy of psychosis by symptom provocation," Comprehensive Psychiatry, vol. 11, no. 1, pp. 80-88, 1970.

[238] F. S. Lansdown, M. Beran, and T. Litwak, "Psychotoxic reaction during ethionamide therapy," American Review of Respiratory Disease, vol. 95, no. 6, pp. 1053-1055, 1967.

[239] W. C. Lewis, G. Calden, J. R. Thurston, and W. E. Gilson, "Psychiatric and neurological reaction tocycloserine in the treatment of tuberculosis," Dis Chest, vol. 32, pp. 172-182, 1957. 
[240] M. Pasargiklian and L. Biondi, "Neurologic and behavioural reactions of tuberculous patients treated with cycloserine," Scandinavian Journal of Respiratory Diseases, vol. 71, pp. 201208, 1970 .

[241] G. Thwaites, M. Fisher, C. Hemingway, G. Scott, T. Solomon, and J. Innes, "British Infection Society guidelines for the diagnosis and treatment of tuberculosis of the central nervous system in adults and children," Journal of Infection, vol. 59, no. 3, pp. 167-187, 2009.

[242] L. Suryananarayan, R. Rajalakshmi, M. V. Jaigopal, and S. G. Radhakrishna, "Performance of national tuberculosis programme during 1996-a report," Indian Journal of Tuberculosis, vol. 46, pp. 11-20, 1999.

[243] W. D. Cuneo and D. E. Snider, "Enhancing patient compliance with tuberculosis therapy," Clinics in Chest Medicine, vol. 10, no. 3, pp. 375-380, 1989.

[244] J. Johnson, A. Kagal, and R. Bharadwaj, "Factors associated with drug resistance in pulmonary tuberculosis," The Indian Journal of Chest Diseases \& Allied Sciences, vol. 45, no. 2, pp. 105-109, 2003.

[245] E. C. Duarte, A. L. Bierrenbach, J. B. da Silva, P. L. Tauil, and E. De Fátima Duarte, "Factors associated with deaths among pulmonary tuberculosis patients: a case control study with secondary data," Journal of Epidemiology and Community Health, vol. 63, no. 3, pp. 233-238, 2009.

[246] A. Kochi, "Tuberculosis control-is dots the health breakthrough of the 1990s?” World Health Forum, vol. 18, no. 3-4, pp. 225-243, 1997.

[247] T. S. Moulding, "Medication monitors to treat tuberculosis: a supplement to directly observed therapy," American Journal of Respiratory and Critical Care Medicine, vol. 159, no. 3, pp. 989991, 1999.

[248] C. L. Fallab-Stubi, J. P. Zellweger, A. Sauty, C. Uldry, D. Iorillo, and M. Burnier, "Electronic monitoring of adherence to treatment in the preventive chemotherapy of tuberculosis," International Journal of Tuberculosis and Lung Disease, vol. 2, no. 7, pp. 525-530, 1998.

[249] M. R. Gasner, K. L. Maw, G. E. Feldman, P. I. Fujiwara, and T. R. Frieden, "The use of legal action in New York City to ensure treatment of tuberculosis," The New England Journal of Medicine, vol. 340, no. 5, pp. 359-366, 1999.

[250] J. R. Cowen and L. O. Gostin, "Controlling the tuberculosis epidemic: the analogy with mental illness," Journal of the American Medical Association, vol. 270, no. 7, p. 832, 1993.

[251] "Global tuberculosis control: surveillance, planning, financing," WHO Report WHO/HTM/TB/2006.362, WHO, Geneva, Switzerland, 2006.

[252] C. P. Chaulk and V. A. Kazandjian, "Directly observed therapy for treatment completion of pulmonary tuberculosis: consensus statement of the public health tuberculosis guidelines panel," Journal of the American Medical Association, vol. 279, no. 12, pp. 943-948, 1998.

[253] E. Vermeire, H. Hearnshaw, P. van Royen, and J. Denekens, "Patient adherence to treatment: three decades of research. A comprehensive review," Journal of Clinical Pharmacy and Therapeutics, vol. 26, no. 5, pp. 331-342, 2001.

[254] T. R. Friedena and J. A. Sbarbarob, "Promoting adherence to treatment for tuberculosis: the importance of direct observation," Bulletin of the World Health Organization, vol. 85, no. 5, pp. 407-409, 2007.
[255] J. Volmink and P. Garner, "Directly observed therapy for treating tuberculosis," Cochrane Database of Systematic Reviews, no. 2, Article ID CD003343, 2006.

[256] K. C. Chang, C. C. Leung, and C. M. Tam, "Risk factors for defaulting from anti-tuberculosis treatment under directly observed treatment in Hong Kong," International Journal of Tuberculosis and Lung Disease, vol. 8, no. 12, pp. 1492-1498, 2004.

[257] T. M. Comolet, R. Rakotomalala, and H. Rajaonarioa, "Factors determining compliance with tuberculosis treatment in an urban environment, Tamatave, Madagascar," International Journal of Tuberculosis and Lung Disease, vol. 2, no. 11, pp. 891897,1998

[258] R. Menzies, I. Rocher, and B. Vissandjee, "Factors associated with compliance in treatment of tuberculosis," Tubercle and Lung Disease, vol. 74, no. 1, pp. 32-37, 1993.

[259] E. Johanson, V. K. Piwan, N. D. Huong, and B. M. Ahlberg, "Staff and patient attitudes to tuberculosis and compliance with treatment," Tubercle and Lung Disease, vol. 77, pp. 178-183, 1996.

[260] J. Dick and J. H. Schoeman, "Tuberculosis in the community: 2. The perceptions of members of a tuberculosis health team towards a voluntary health worker programme," Tubercle and Lung Disease, vol. 77, no. 4, pp. 380-383, 1996.

[261] A. J. Rubel and L. C. Garro, "Social and cultural factors in the successful control of tuberculosis," Public Health Reports, vol. 107, no. 6, pp. 626-635, 1992.

[262] S. A. Erika, J. P. Kircht, and M. H. Becker, "Understanding and improving patient compliance," Annals of Internal Medicine, vol. 100, pp. 258-268, 1984.

[263] R. Horne and J. Weinman, "Patients' beliefs about prescribed medicines and their role in adherence to treatment in chronic physical illness," Journal of Psychosomatic Research, vol. 47, no. 6, pp. 555-567, 1999.

[264] P. Farmer, S. Robin, S. L. Ramilus, and J.Y. Kim, "Tuberculosis, poverty, and "compliance": lessons from rural Haiti," Seminars in Respiratory Infections, vol. 6, no. 4, pp. 254-260, 1991.

[265] K. Chani, "Factors affecting compliance to tuberculosis treatment in Andara Kavango region Namibia," 2010.

[266] C. K. Liam, K. H. Lim, C. M. M. Wong, and B. G. Tang, "Attitudes and knowledge of newly diagnosed tuberculosis patients regarding the disease, and factors affecting treatment compliance," International Journal of Tuberculosis and Lung Disease, vol. 3, no. 4, pp. 300-309, 1999.

[267] R. A. Sansone, Sansone, and LA, "Alcohol/ substance misuse and treatment: fatal attraction," Psychiatry, vol. 5, no. 9, pp. 4346, 2008.

[268] D. Armstrong, "From clinical gaze to regime of total health," in Working for Health, T. Heller, R. Muston, M. Sidell, and C. Lloyd, Eds., pp. 16-27, Sage, London, UK, 2000.

[269] A. Jaiswal, V. Singh, J. A. Ogden et al., "Adherence to tuberculosis treatment: lessons from the urban setting of Delhi, India," Tropical Medicine and International Health, vol. 8, no. 7, pp. 625633, 2003.

[270] A. 1. Muñoz Sanches and M. R. Bertolozzi, "Pode o conceito de vulnerabilidade apoiar a construção do conhecimento em Saúde Coletiva?" Ciência \& Saúde Coletiva, vol. 12, no. 2, pp. 319-324, 2007.

[271] A. I. M. Sanchez and M. R. Bertolozzi, "Beyond dots (directly observed treatment short-course) in tuberculosis' control: interfacing and sharing needs," Revista Latino-Americana de Enfermagem, vol. 17, no. 5, pp. 689-694, 2009. 
[272] R. S. Fry, K. Khoshnood, E. Vdovichenko et al., "Barriers to completion of tuberculosis treatment among prisoners and former prisoners in St Petersburg, Russia," International Journal of Tuberculosis and Lung Disease, vol. 9, no. 9, pp. 1027-1033, 2005.

[273] J. Acha, A. Sweetland, D. Guerra, K. Chalco, H. Castillo, and E. Palacios, "Psychosocial support groups for patients with multidrug-resistant tuberculosis: five years of experience," Global Public Health, vol. 2, no. 4, pp. 404-417, 2007.

[274] J. Macqa, A. Solisb, and G. Martinezb, "Assessing the stigma of tuberculosis," Psychology, Health \& Medicine, vol. 11, no. 3, pp. 346-352, 2006.

[275] A. D. Jiminez, "Playing the blame game: casting guilt and avoiding stigma during a tuberculosis health crisis," International Journal of Sociology and Social Policy, vol. 23, no. 6-7, pp. 80113, 2003.

[276] A. K. Janmeja, S. K. Das, R. Bhargava, and B. S. Chavan, "Psychotherapy improves compliance with tuberculosis treatment," Respiration, vol. 72, no. 4, pp. 375-380, 2005.

[277] E. S. Pevzner, S. Robison, J. Donovan et al., “Tuberculosis transmission and use of methamphetamines in Snohomish County, WA, 1991-2006," American Journal of Public Health, vol. 100, no. 12, pp. 2481-2486, 2010.

[278] S. F. Greenfield, A. Shields, H. S. Connery et al., "Integrated management of physician-delivered alcohol care for tuberculosis patients: design and implementation," Alcoholism, vol. 34, no. 2, pp. 317-330, 2010.

[279] Revised National Tuberculosis Control Programme DOTS-Plus Guidelines, Central TB Division, Directorate General of Health Services, Ministry of Health \& Family Welfare Nirman Bhavan, New Delhi, India, 2010.

[280] S. P. Dearman, W. Waheed, Whitehead, and C. Dickens, "Role of depression and illness perception in poor compliance in Tuberculosis.," in Proceedings of the European Association for Consultation-Liaison Psychiatry and Psychosomatics (Conference Abstracts), Berlin, Germany, 2004.

[281] V. Patel, R. Araya, and P. Bolton, "Treating depression in the developing world," Tropical Medicine and International Health, vol. 9, no. 5, pp. 539-541, 2004.

[282] N. N. Hansel, A. W. Wu, B. Chang, and G. B. Diette, "Quality of life in tuberculosis: patient and provider perspectives," Quality of Life Research, vol. 13, pp. 639-652, 2004.

[283] WHO, Adherence to Long Term Therapies: Evidence for Action, World Health Organization, Geneva, Switzerland, 2003, http://www.who.int/chp/knowledge/publications/adherence full_report.pdf.

[284] F. Barnhoorn and H. Adriaanse, "In search of factors responsible for noncompliance among tuberculosis patients in Wardha District, India," Social Science and Medicine, vol. 34, no. 3, pp. 291-306, 1992.

[285] J. I. Mata, "Integrating the client's perspective in planning a tuberculosis education and treatment program in Honduras," Medical Anthropology, vol. 9, no. 1, pp. 57-64, 1985.

[286] S. A. Lewin, Z. C. Skea, V. Entwistle, M. Zwarenstein, and J. Dick, "Interventions for providers to promote a patientcentred approach in clinical consultations," Cochrane Database of Systematic Reviews, no. 4, Article ID CD003267, 2001.

[287] P. Garner, H. Smith, S. Munro, and J. Volminkc, "Promoting adherence to tuberculosis treatment," Bulletin of the World Health Organization, vol. 85, no. 5, pp. 404-406, 2007.
[288] H. C. Wichowski and S. M. Kubsch, "The relationship of selfperception of illness and compliance with health care regimens," Journal of Advanced Nursing, vol. 25, no. 3, pp. 548-553, 1997.

[289] D. S. Robinson, W. Lovenberg, H. Keiser, and A. Sjoerdsma, "Effects of drugs on human blood platelet and plasma amine oxidase activity in vitro and in vivo," Biochemical Pharmacology, vol. 17, no. 1, pp. 109-119, 1968. 


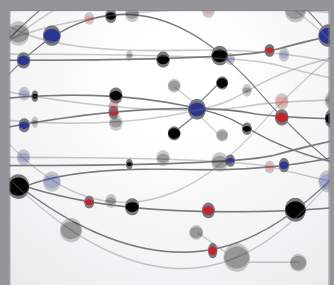

The Scientific World Journal
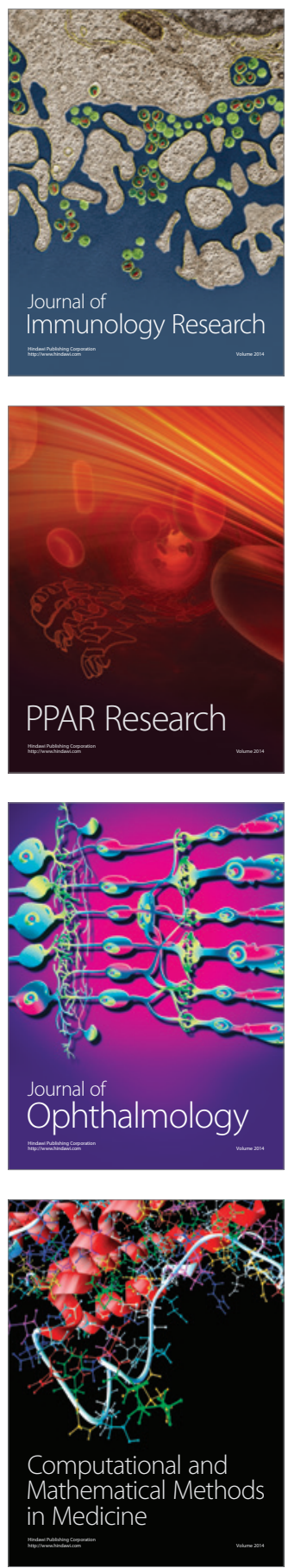

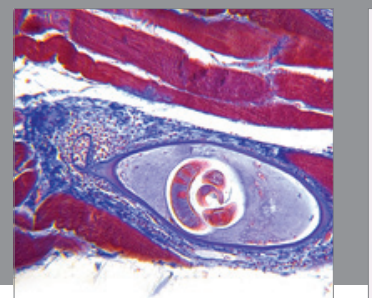

Gastroenterology

Research and Practice
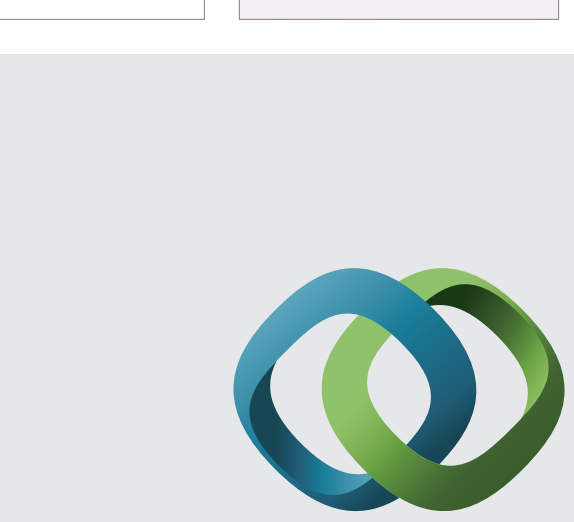

\section{Hindawi}

Submit your manuscripts at

http://www.hindawi.com
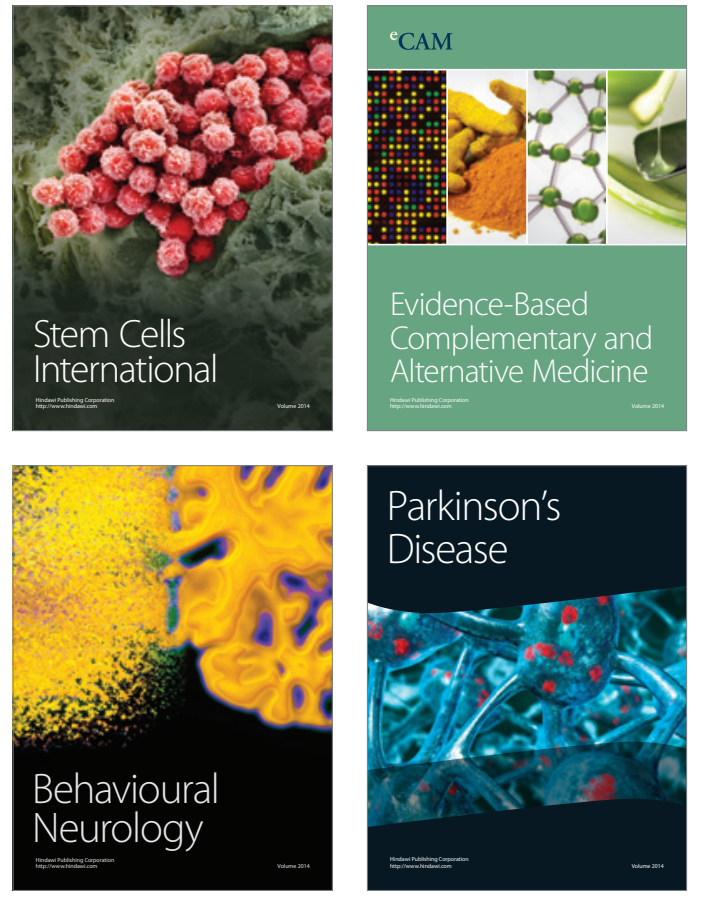
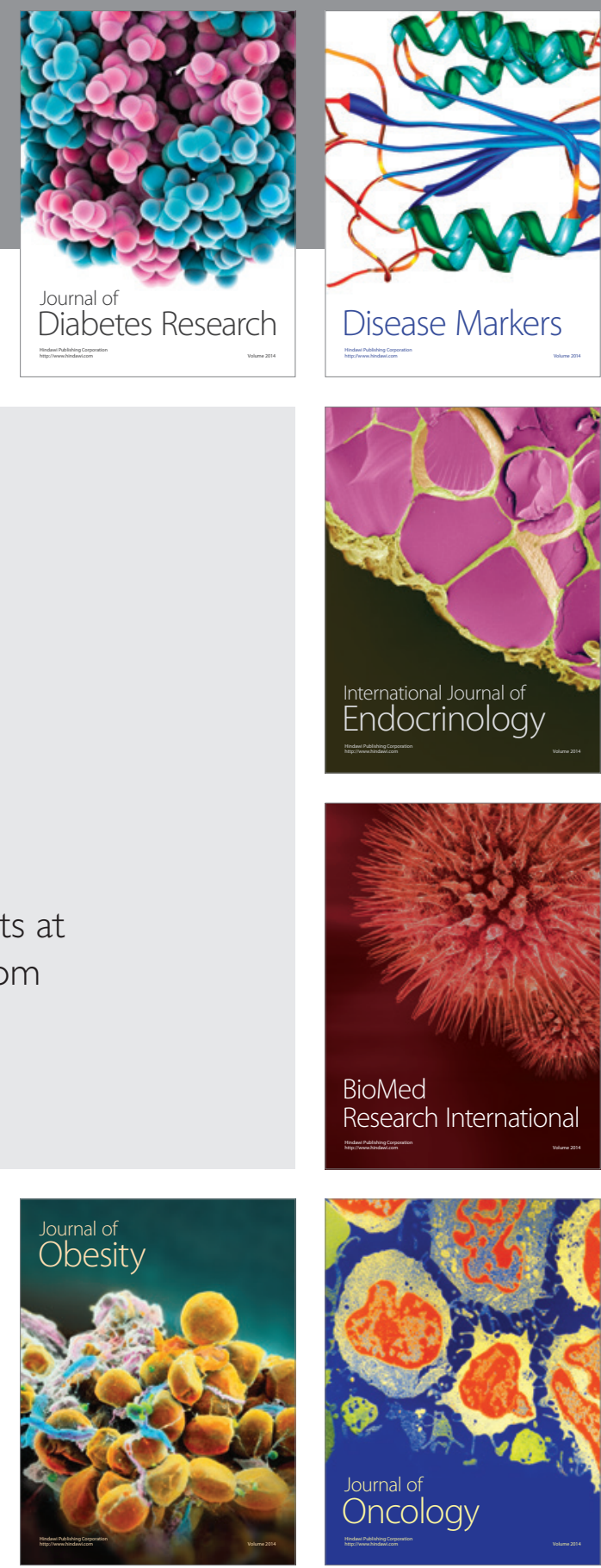

Disease Markers
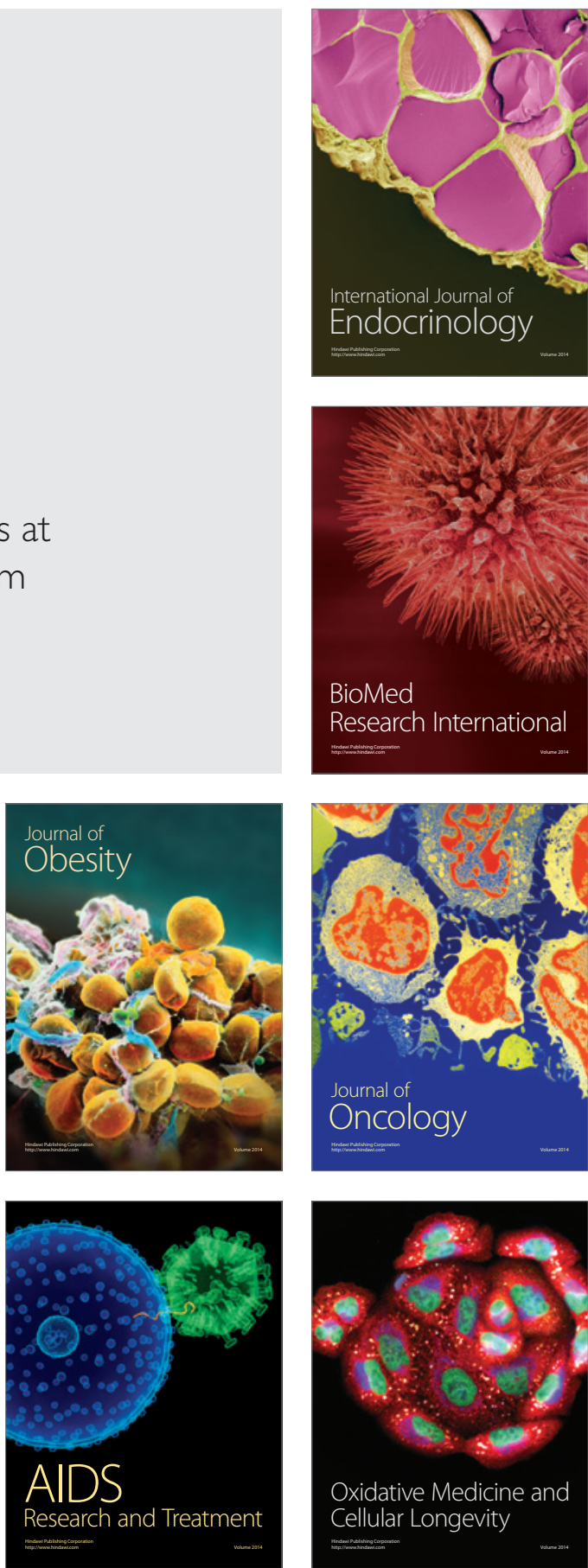